\title{
Lithostratigraphy and Geochemistry of Upper Vendian-Lower Cambrian Deposits in the Northeastern Baltic Monocline
}

\author{
V. N. Podkovyrov ${ }^{a}$, A. V. Maslov ${ }^{b}$, A. B. Kuznetsov ${ }^{a}$, and V. B. Ershova ${ }^{c}$ \\ ${ }^{a}$ Institute of Precambrian Geology and Geochronology, Russian Academy of Sciences, St. Petersburg, 199034 Russia \\ ${ }^{b}$ Zavaritskii Institute of Geology and Geochemistry, Ural Branch, Russian Academy of Sciences, Yekaterinburg, 620016 Russia \\ ${ }^{c}$ St. Petersburg State University, St. Petersburg, 199034 Russia \\ e-mail:vpodk@mail.ru \\ Received November 25, 2015; in final form, January 18, 2016
}

\begin{abstract}
The results of investigations of Upper Vendian-Lower Cambrian deposits in the northeastern part of the Baltic monocline specify views on the evolution of depositional environments of sedimentary successions constituting the basal part of the sedimentary cover in inner areas of the northwestern East European Platform. It is shown that the Late Vendian and initial Cambrian were characterized by the consecutive influx of relatively mature terrigenous detrital material that originated from both the weathering crust of the Baltic Shield and new sources. Its deposition was interrupted by notable, although likely asynchronous, hiatuses, which are registered at the base of the Upper Vendian Vasileostrovskaya and Voronkovo formations and Lower Cambrian Lomonosov Formation. In the Late Vendian, sedimentary material was transported from the Baltic Shield, while beginning from the initial Early Cambrian the additional contribution to the formation of the sedimentary cover of the Baltic monocline was provided by coarse-grained sedimentary material from the Timan margin of the Baltica as follows from $\mathrm{U}-\mathrm{Pb}$ isotopic ages obtained for detrital zircons. At the same time, lithogeochemical parameters of fine-grained rocks experienced no substantial changes.
\end{abstract}

Keywords: lithostratigraphy, geochemistry, terrigenous rocks, Vendian, Cambrian, Baltic monocline, East European Platform

DOI: $10.1134 / \mathrm{S} 086959381606006 \mathrm{X}$

\section{INTRODUCTION}

The Upper Vendian-Lower Cambrian transitional deposits in the northeastern part of the Baltic monocline are represented by the Valdai and Baltic groups (Resheniya..., 1965). The Valdai Group, which rests in the region under consideration transgressively upon the pre-Riphean crystalline basement of the East European Platform, includes the Upper Vendian Redkino and Kotlin regional stages (Aksenov et al., 1978; Gnilovskaya et al., 1979; Sokolov and Fedonkin, 1985; Grazhdankin and Maslov, 2015). The Baltic Group in the examined sections is represented by the Lower Cambrian Lomonosov and Lontova (Siverskaya) formations (Resheniya..., 1965; Stratigrafiya..., 1979).

The mineralogical and isotopic $(\mathrm{Rb}-\mathrm{Sr}$ and $\mathrm{Sm}-\mathrm{Nd}$ ) investigations of "blue clays" from the Lontova regional stage of the Lower Cambrian Baltic Group revealed the existence of two illite generations (Gorokhov et al., 1994, 2007). One of the generations (authigenic) made it possible to estimate the age of early diagenesis (close to age of sedimentation) of Lower Cambrian clayey sediments: approximately $533 \pm 8 \mathrm{Ma}$
(Gorokhov et al., 1994). The second coarse generation of illite with an insignificant admixture of chlorite (detrital) resulted from rock transformation in provenances. The $\mathrm{Rb}-\mathrm{Sr}$ and $\mathrm{Sm}-\mathrm{Nd}$ investigations of the detrital illite generation reveal that the minimum age of eroded rocks in the northwestern areas of the East European Platform is constrained by the interval of 790-720 Ma (Gorokhov et al., 2007).

The purpose of this work consists in considering the main trends of changes in lithochemical and geochemical properties of terrigenous rock from the Upper Vendian Staraya Russa, Vasileostrovskaya, and Voronkovo formations and overlying Lomonosov and Siverskaya formations of the Baltic Group, as well as their correlation with similar trends established for Upper Vendian sections of the southeastern Belomorian region, southeastern Mezen syneclise, and western slope of the Middle Urals (Maslov and Podkovyrov, 2010; Maslov et al., 2013). The investigations are based on the data derived from the study of core sections from the recently drilled Utkina Zavod (St. Petersburg), Korov'e-8 (right side of the Syas River in its lower reaches), and Shotkusa-1 (area of the 


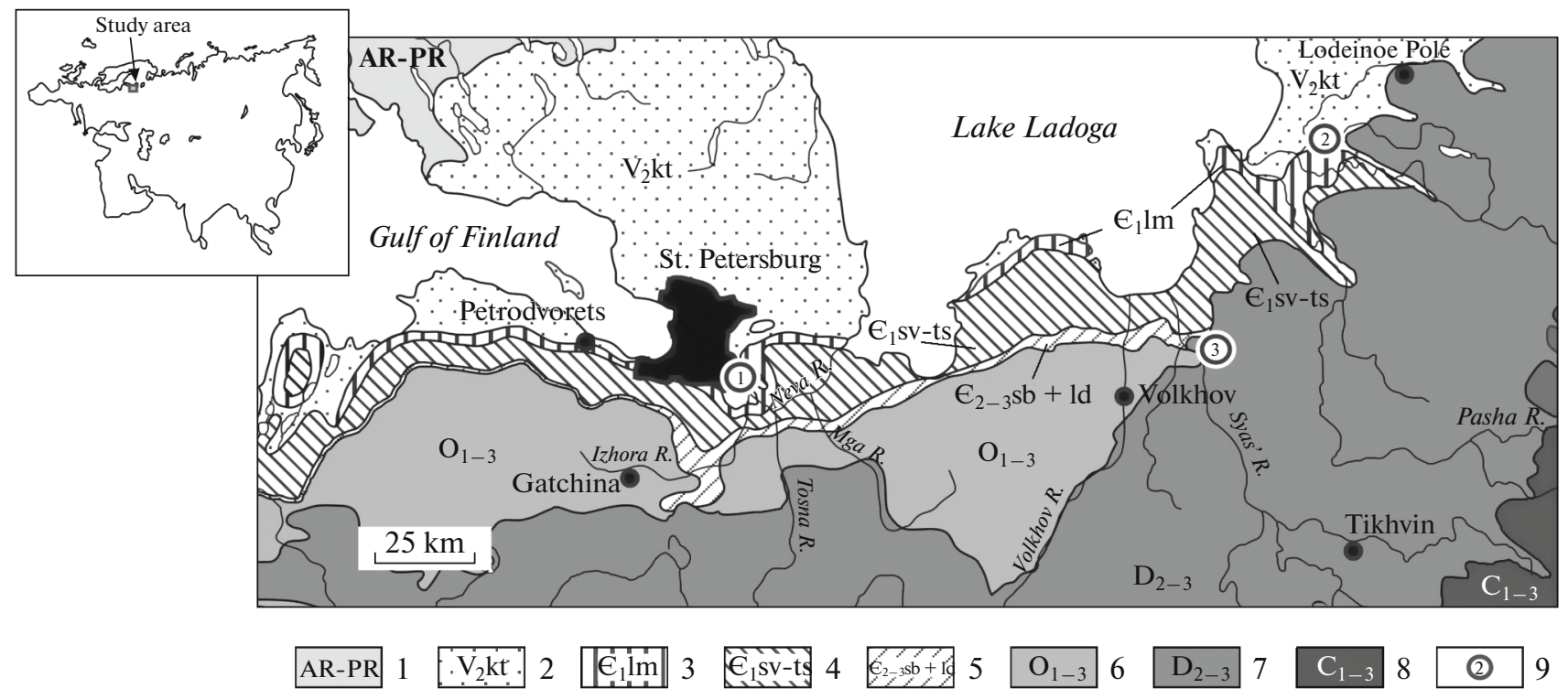

Fig. 1. Schematic geological map of the northeastern Baltic monocline (modified after Verbitskii et al., 2012) and position of investigated borehole sections. (1) Archean-Proterozoic; (2) Upper Vendian (Kotlin regional stage); (3) Lower Cambrian (Lomonosov Formation); (4) Lower Cambrian (Siverskaya, Lyukati, and Tiskres formations); (5) Middle-Upper Cambrian (Sablino and Ladoga formations); (6) Ordovician; (7) Middle-Upper Devonian; (8) Carboniferous deposits, undivided; (9) position of investigated borehole sections: (1) Utkina Zavod, (2) Shotkusa-1, (3) Korov’e-8.

like-named station of the Oktyabrsk railway) boreholes (Fig. 1). These investigations are of importance for understanding the history of formation of the Vendian-Cambrian sedimentary cover of the Baltica paleocontinent, reconstructing depositional environments for terrigenous deposits, revealing provenances, and, finally, specifying stratigraphic scales available for Vendian-Cambrian boundary deposits of the Moscow syneclise.

\section{LITHOSTRATIGRAPHY OF SEDIMENTARY SUCCESSIONS AND SEDIMENTARY SYSTEMS}

In this work, stratigraphic subdivision of Vendian-Cambrian sections in the northeastern part of the Baltic monocline is accepted in accordance with the General Stratigraphic Scale (GSS) of Russia (Zhamoida, 2013).

Staraya Russa Formation. This stratigraphic unit attributed to the Upper Vendian Redkino regional stage is defined on the outskirts of St. Petersburg and east of it at the base of the Valdai Group (Postanovleniya..., 2011; Verbitskii et al., 2012). The type section of the formation is recovered by a well in the town of Staraya Russa in Novgorod oblast (depth interval of 920-873 m) (Geisler, 1967). The rocks constituting the formation extend in the form of sublatitudinal band from the town of Lomonosov to eastern Leningrad oblast, where they are overlain by Paleozoic or Quaternary strata. Its thickness amounts to $50 \mathrm{~m}$. In the examined Utkina Zavod and Shotkusa-1 borehole sections, the basal part of the formation encloses relicts of the disintegrated and reworked weathering crust developed after the pre-Riphean basement or Riphean sandy-gravelite deposits. The lower part of the Staraya Russa Formation is represented in the Utkina Zavod borehole section by sandstones with siltstone and mudstone intercalations, while in the Volkhov-Syas' river interfluve, it is dominated by sandy mudstones with intercalations of clayey pudding sandstones up to a few meters thick. The upper part of the section up to 35-45 $\mathrm{m}$ thick is composed of variegated mudstones with cracks filled with sandy-silty material, implying locally subaerial depositional environments.

The study of the section recovered by Shotkusa-1 borehole and its correlation with other sections of the Staraya Russa Formation shows that its lower subformation (interval of 267.0-248.9 m) above the unconformable contact with quartzose sandstones of the presumably Lower Riphean Priozersk Formation in the interval of $267-260 \mathrm{~m}$ is dominated by bluish gray silty mudstones overlain by a bed ( $0.5-0.7 \mathrm{~m}$ thick) of quartzose sandstones. In its basal part (interval of 258.4$248.9 \mathrm{~m}$ ), the upper subformation of the Staraya Russa Formation (interval of 258.4-217.0 m) is composed of frequently alternating greenish gray and brown mudstones and siltstones with thin lenticular intercalations of pudding feldspar-quartz sandstones. The interval of $248.0-228.3 \mathrm{~m}$ is represented by alternating packets $(0.8-2.0 \mathrm{~m})$ of massive and thin-bedded bluish gray and brown silty mudstones with rare laminae of finegrained sandstones. In the interval of 228.3-217.0 m, 
the dominant role belongs to thin-bedded brown and bluish gray mudstones with ankerite laminae. ${ }^{1}$

Mudstones of the Staraya Russa Formation are composed of illite, kaolinite, and mixed layer smectite-illite, which is consistent with the data obtained previously for mudstones of the Redkino regional stage in the region under consideration (Gorokhov et al., 1994), and inequigranular clastic material dominated by quartz with a subordinate quantity of microcline, muscovite, chlorite, and chloritized biotite. These rocks contain also pyrite, including its framboidal varieties $(5-15 \mu \mathrm{m})$. Sandstones of the Staraya Russa Formation are inequigranular, quartz-feldspar, with clay-quartz and carbonate (ankerite-siderite) cement.

The sedimentary system of the Staraya Russa Formation includes deposits of the transgressive tract of the lower subformation and regressive tract of the upper subformation, which were formed in submarine river fan settings and low-energy environments of sea shoals (zones of weak currents and waves) (Podkovyrov, 2010).

In the region under consideration, the Vasileostrovskaya and Voronkovo formations overlying the Staraya Russa Formation (Fig. 2) are attributed to the Kotlin regional stage defined as the upper part of the Valdai Group corresponding to laminarite clays of the East European Platform (Resheniya..., 1965; Verbitskii et al., 2012). The views on the stratigraphic position of this regional stage and its biostratigraphic characteristic are summarized in (Mens and Pirrus, 1971; Gnilovskaya et al., 1979; Stratigrafiya..., 1979; Aksenov, 1985; Burzin, 1996).

Vasileostrovskaya Formation. The formation 150$170 \mathrm{~m}$ thick either rests conformably upon the Staraya Russa Formation in the eastern part of the region in question (Shotkusa-1 borehole) or is separated from it by unconformity (Utkina Zavod borehole) coinciding with the surface of maximum regression (Podkovyrov, 2010). The formation unites the lower sandy-clayey and upper substantially clayey subformations. The section of the lower subformation is represented by alternating brownish and greenish gray silty mudstones and gray micaceous sandstones; the upper subformation is composed of greenish and bluish gray laminarite clays with sandstone intercalations (Verbitskii et al., 2012).

In the Utkina Zavod borehole section, the lower subformation of the Vasileostrovskaya Formation is represented by a sequence (up to $12-13 \mathrm{~m}$ thick) of thin-bedded variegated silty mudstones with intercalations of gray micaceous sandstones. In the Shotkusa-1 borehole, it corresponds likely to a member of

\footnotetext{
${ }^{1}$ Carbonate minerals of the $\mathrm{Ca}-\mathrm{Fe}-\mathrm{Mg}$ mineral phases (ankerite, ankerite-siderite, $\mathrm{Fe}$ dolomite, $\mathrm{Fe}$ calcite, dolomite) and clay minerals were identified at the Institute of Precambrian Geology and Geochronology on a the JEOL electron microscope with a LINK spectrometer.
}

light pinkish feldspar-quartz sandstones and silty sandstones with kaolinite cement (interval of 217-210 m), which is replaced higher in the section (interval of $210-195 \mathrm{~m}$ ) by light quartzose sandstones with silty mudstone intercalations. It is conceivable that some of these rocks are composed of products of the reworked weathering crust, which is evident from the presence of intercalations of tobacco pink silty mudstones with quartz and K-rich feldspar grus. This interval of the Shotkusa-1 borehole section may be correlated with the lower subformation of the Vasileostrovskaya Formation in its type section (Geolkom borehole, VSEGEI museum, St. Petersburg). In the Korov'e- 8 borehole, the lower part of the formation is likely not recovered.

The upper subformation of the Vasileostrovskaya Formation is up to $140 \mathrm{~m}$ thick. In Utkina Zavod borehole section, it is composed of homogeneous succession of greenish gray laminarite clays with fine horizontal and wavy bedding and siderite inclusions either disseminated or in the form of intercalations and rare beds of gray micaceous feldspar-quartz sandstones. The uppermost part of the formation cropping out on the southern shore of the Gulf of Finland includes ferruginate silty mudstones with intraclasts of poorly consolidated siltstones, which evidently represent cracking crusts formed after sedimentation break and consolidation of underlying sediments (Hagen-Thorn, 2012).

Clayey rocks in the upper subformation of the Vasileostrovskaya Formation are largely composed of kaolinite and illite with an admixture of chlorite and, locally, mixed-layer smectite-illite mineral. The assemblage of detrital minerals in silty mudstones of the Vasileostrovskaya Formation is dominated by quartz, muscovite, and chloritized biotite accompanied by subordinate microcline. Chlorite and ankerite-siderite form peculiar "porphyry-like phenocrysts." There is framboidal pyrite as well.

In the Korov'e- 8 borehole section, analogs of the upper subformation of the Vasileostrovskaya Formation (interval of 260.0-232.4) are represented in its lower part (interval of $260-250 \mathrm{~m}$ ) by alternating dark gray silty mudstones with intercalations of gray siltstones. Mudstones include abundant laminae of moderately and poorly sorted and rounded silty-sandy material including quartz grains likely of eolian origin. Cement in sandstones is composed of kaolinite and Fe dolomite. The higher interval $(250.0-232.4 \mathrm{~m})$ is dominated by dark gray mudstones intercalated by thin layers of gray silty sandstones.

A similar structure and composition of rocks in the upper subformation of the Vasileostrovskaya Formation is also observable in the Shotkusa-1 well borehole section (interval 195-96 m), where it is composed of horizontally and gentle wavy bedded brown and gray, frequently spotty silty mudstones with intercalations of light siltstones and fine-grained sandstones with kaolinite cement. In the uppermost part of the subfor- 
PODKOVYROV et al.

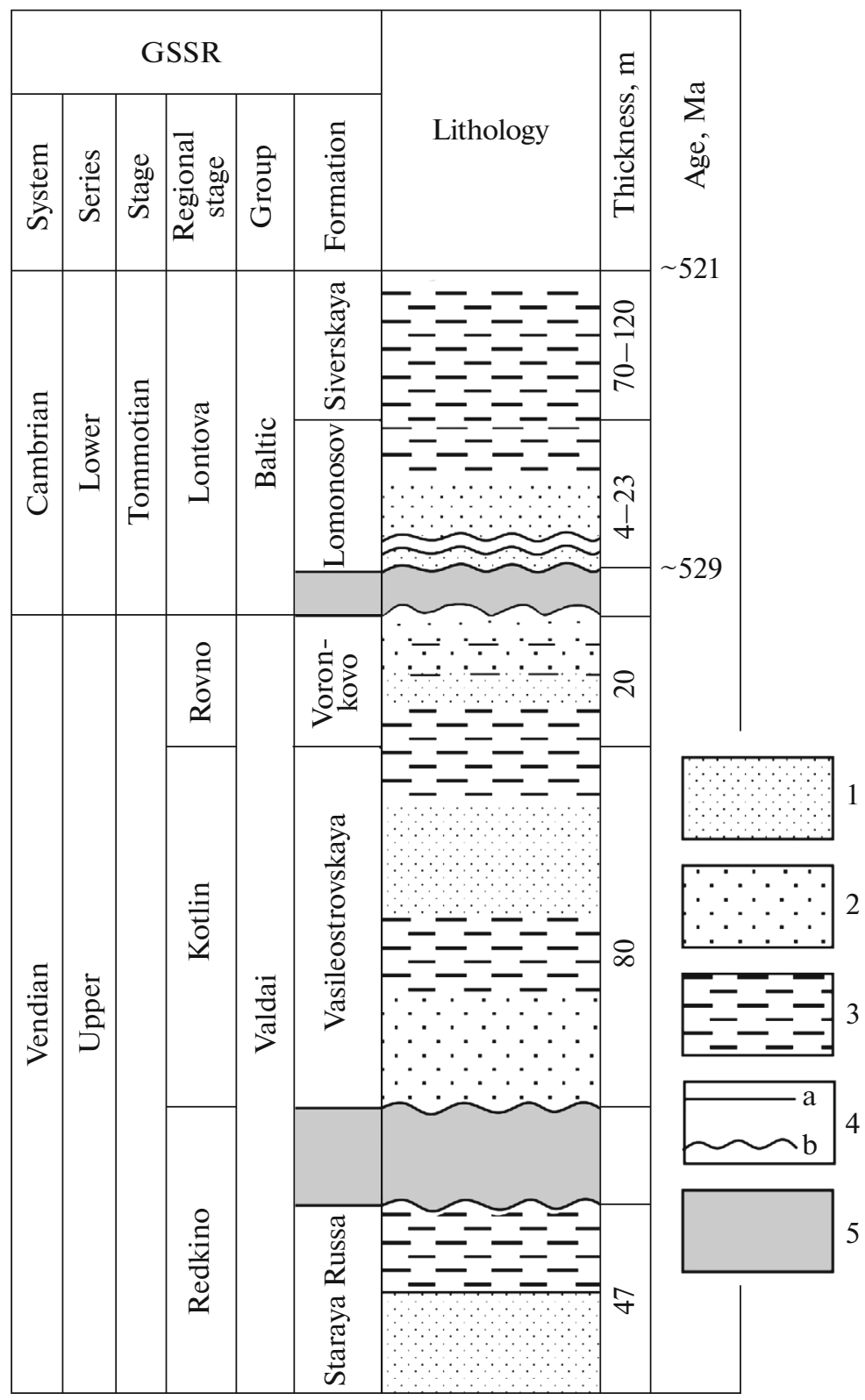

Fig. 2. Composite Upper Vendian-Lower Cambrian stratigraphic section of the northeastern Baltic monocline (slightly modified after Põldvere et al., 2014). (1) Sandstones; (2) siltstones; (3) clays; (4) stratigraphic boundaries: (a) conformable, (b) unconformable; (5) stratigraphic hiatuses. (GSSR) General Stratigraphic Scale of Russia.

mation, siltstones are bluish gray; silty mudstones are mostly brown with laminae of greenish gray varieties.

The sediments of the Vasileostrovskaya Formation accumulated under conditions of cyclic migration of facies belts ("zone of subaerial and coastal marine plain sediments-zone of calm sea and weak currents-zone of stagnant depressions in the sublittoral bottom") and relatively high sea level stand (Podkovyrov, 2010).

Voronkovo Formation. The section of the Kotlin regional stage is crowned by deposits of the Voronkovo Formation cropping out on the southern shore of the
Gulf of Finland in the mouth area of the Voronka River. This section up to $15 \mathrm{~m}$ thick is composed of alternating gray cross-bedded feldspar-quartz sandstones, thinbedded bluish and tobacco gray mudstones, bluish gray sandy siltstones, and pinkish gray ferruginate sandstones (Hagen-Thorn, 2012). The formation is terminated by a layer of bright yellow clays with lepidocrocite overlain by a member of kaolinitized and limonitized quartzose sandstones (up to $4.5 \mathrm{~m}$ thick).

The clayey fraction in silty mudstones of the Voronkovo Formation is dominated by illite, kaolinite, and chlorite accompanied by subordinate mixed- 
layer mineral of the smectite-illite type. The clayey groundmass includes sporadic large quartz, glauconite, microcline, and pyrite grains. The heavy fraction contains mostly rutile, epidote, and zircon.

As a whole, the Kotlin stage in the evolution of the Late Vendian basin in the region under consideration unites three relatively short-term sedimentation cycles represented by the lower (Gdov Beds) and upper (Kotlin Beds) subformations of the Vasileostrovskaya Formation and the conformably overlying Voronkovo Formation (Fig. 2). The sea flooding surface at the base of the Kotlin regional stage reflects a major eustatic event, which is readily recognizable also on the eastern margin of the East European Platform (Grazhdankin and Maslov, 2009). The relative isolation of some parts of the Kotlin paleobasin in the northwestern and northeastern areas of the East European Platform and wide development of moderately stagnant settings were probably responsible for the specific composition of organic remains in sediments of this stage: dominant Vendotaenia flora and extremely scarce findings of impressions of soft-bodied organisms (Gnilovskaya et al., 1979; Grazhdankin et al., 2011; Marusin et al., 2011).

It is impossible now to unambiguously establish the position of the lower boundary of the Cambrian System in the East European Platform (Grazhdankin and Maslov, 2015). It is known that the Vendian-Cambrian boundary in the Baltic region west of the region in question corresponds to a major stratigraphic hiatus at the base of the Cambrian Lontova regional stage (Mens and Pirrus, 1971; Stratigrafiya..., 1979; Sokolov and Fedonkin, 1985; Jensen and Mens, 2001). In the northeastern part of the Baltic monocline east-southeast of St. Petersburg, transition from deposits of the Kotlin regional stage (Voronkovo Formation) to rocks of the Lower Cambrian Lomonosov Formation is usually gradual (Geologicheskii..., 2009; Hagen-Thorn, 2012).

Judging from their lithological and mineralogical properties, transitional Vendian-Cambrian deposits in the region under consideration are the most completely represented in the Korov'e- 8 borehole section. In this section, the interval of $232-213 \mathrm{~m}$ is composed of greenish gray silty mudstones with dark brown organic films and microaggregates of framboidal pyrite on bedding planes and rare intercalations of light subarkosic sandstones. In the interval of $217-213 \mathrm{~m}$ of the Korov'e- 8 borehole section, bedding surfaces exhibit impressions of deposit feeder crawling traces (probably, Treptichnus pedum; Golubkova et al., 2016).

In the investigated area of the Baltic monocline, sedimentary rocks of the Baltic Group overlying Vendian deposits are united into the Lomonosov and Siverskaya formations (Resheniya.., 1965; Stratigrafiya..., 1979).

Lomonosov Formation. This unit resting either conformably or with the erosional surface upon underlying deposits is composed of irregularly alternating sandstones, siltstones, and clays. Its thickness varies from a few meters to $45-50 \mathrm{~m}$. Sandstones and siltstones constituting the lower part of the formation are inequigranular, light to pinkish in color, thin horizontally, and cross-bedded. Sandstones are largely quartzose $(>60-80 \%)$, with an insignificant admixture of feldspars and mica. Cement is of the contact type, clay-quartz by composition, with spots of carbonate and pyrite. The heavy fraction includes zircon, amphibole, kyanite, pyrite, glauconite, and rare siderite or ankerite. Pyrite is frequently represented both by aggregates of crystals and in the form of framboids. Clays are greenish gray, sandy-silty and form laminae and lenses, exhibiting films of organic matter and fine crystalline pyrite on bedding planes. Clayey rocks of this formation are usually composed of dominant illite, chlorite, and mixed-layer smectite-illite minerals with an admixture of kaolinite (Gorokhov et al., 1994). The assemblage of accessory minerals includes apatite, siderite, and Fe hydoxides (Gorokhov et al., 2007). Clastic material in clays is represented by quartz, K-rich feldspar, chloritized biotite, and muscovite. The rocks of the Lomonosov Formation contain remains of Sabellidites cambriensis and Serpulites petropolitanus characteristic of the Tommotian Stage (Dronov et al., 2005). The formation is overlain by deposits of the Siverskaya Formation of the Lower Cambrian Lontova regional stage.

Siverskaya Formation. The deposits of the Siverskaya Formation ("blue clay" member) crop out in the form of a latitudinal band in the fore-clint zone extending between the Narva and Syas rivers (Fig. 1). Like the underlying deposits, the rocks of the formation dip gently in the southeasterly direction under younger Paleozoic strata. The thickness of the formation in Leningrad oblast varies from 100 to $120-130 \mathrm{~m}$ (Dronov et al., 2005). The formation is represented by a clay sequence with rare sandstone and siltstone intercalations. Clays are frequently sandy, spotty-banded (greenish and reddish gray), with chlorite-illite concretions with single crystals of pyrite and kaolinite admixture and pyrite films. Sandstones and siltstones are composed of feldspar and quartz with inclusions of pyrite and glauconite. Cement in sandstones is clayey-carbonate, locally carbonate.

The Siverskaya Formation encloses abundant remains of Sabellidites cambriensis, Platysolenites antiguissimus, Serpulites petropolitanus, and other Early Cambrian fossils. In Leningrad oblast, the section of the Siverskaya Formation is overlain with an insignificant stratigraphic unconformity by the Lyukati Formation of the Dominopol regional stage of the Lower Cambrian Atdabanian Stage (Dronov et al., 2005), and in the eastern areas, by sands and sandstones of the Middle Cambrian Sablino Formation. 


\section{MATERIALS AND ANALYTICAL METHODS}

In this work, we use the data on contents of the main rock-forming oxides and several minor and trace elements in terrigenous rocks of a wide lithological spectrum. At the same time, the main inferences are derived from the analysis of the whole-rock chemical composition of aluminosilicate clastic rocks: Upper Vendian and Lower Cambrian mudstones and siltstones recovered by the three main boreholes-Utkina Zavod, Korov'e-8, and Shotkusa-1.

The contents of petrogenic oxides were determined in 128 samples in the chemical laboratory of the Russian Geological Research Institute (VSEGEI) by the X-ray fluorescence method on an ARL 9800 spectrometer (St. Petersburg, analyst B.A. Tsimoshenko) and at the Zavaritsky Institute of Geology and Geochemistry (Yekaterinburg) by the RFA method on CPM-18 and XRF-1800 devices (analysts N.P. Gorbunova, L.A. Tatarinova, V.P. Vlasov, G.S. Neupokoeva, and G.M. Yatluk). The contents of trace elements were established in the same laboratories by the methods of atomic absorption, quantitative spectral analysis, and ICP-MS (Optima 4300DV spectrometer and ELAN 6100 DRC mass spectrometer). The mineral composition of rocks was determined in polished thin sections with a JEOL electron microscope and by the standard X-ray phase analysis at the Institute of Precambrian Geology and Geochronology.

The $\mathrm{U}-\mathrm{Pb}$ dating of zircons was conducted by the LA-ICP-MS method at the University of Texas (Austin, USA) on a Thermo Element 2 mass spectrometer with a $193 \mathrm{~nm}$ excimer laser (analysts V.B. Ershova and $\mathrm{O}$. Anfison).

\section{LITHOGEOCHEMISTRY OF FINE-GRAINED DETRITAL ROCKS}

The lithogeochemical data give in some cases reason to revise some views on the formation of sedimentary successions of different ages and assess the contribution of large eroded provenances to their composition (Rollinson, 1994; Interpretatsiya..., 2001; Maslov, 2005).

Approaches to and methods of data interpretation. For reconstructing paleoclimatic conditions during the formation of terrigenous rocks, a wide spectrum of approaches is used: from different modules/ratios between rock-forming oxides (hydrolysate $\left(\mathrm{Al}_{2} \mathrm{O}_{3}+\right.$ $\left.\mathrm{TiO}_{2}+\mathrm{Fe}_{2} \mathrm{O}_{3}+\mathrm{FeO}+\mathrm{MnO}\right) / \mathrm{SiO}_{2}$, aluminosilicate $\mathrm{Al}_{2} \mathrm{O}_{3} / \mathrm{SiO}_{2}$, and others) and indices (chemical index of alteration, CIA: $100 \cdot \mathrm{Al}_{2} \mathrm{O}_{3} /\left(\mathrm{Al}_{2} \mathrm{O}_{3}+\mathrm{CaO}+\mathrm{Na}_{2} \mathrm{O}+\right.$ $\mathrm{K}_{2} \mathrm{O}$ ); chemical index of weathering, CIW: 100 . $\mathrm{Al}_{2} \mathrm{O}_{3} /\left(\mathrm{Al}_{2} \mathrm{O}_{3}+\mathrm{CaO}+\mathrm{Na}_{2} \mathrm{O}\right)$; and others) (Nesbitt and Young, 1982; Cox et al., 1995; Fedo et al, 1995; Yudovich and Ketris, 2000; Interpretatsiya..., 2001) to paired and triangle diagrams $((\mathrm{CaO}+\mathrm{MgO}+\mathrm{FeO}+$ $\mathrm{Fe}_{2} \mathrm{O}_{3}+\mathrm{Na}_{2} \mathrm{O}+$ 1.o.i. $)-\left(\mathrm{Al}_{2} \mathrm{O}_{3}+\mathrm{TiO}_{2}\right)-\left(\mathrm{SiO}_{2}+\right.$
$\mathrm{K} 2 \mathrm{O}),\left(\mathrm{Al}_{2} \mathrm{O}_{3}+\mathrm{K}_{2} \mathrm{O}+\mathrm{Na}_{2} \mathrm{O}\right)-\mathrm{SiO}_{2}, \mathrm{~A}-\mathrm{CN}-\mathrm{K}$, $(\mathrm{A}-\mathrm{K})-\mathrm{C}-\mathrm{N}$, and others) (Ronov and Khlebnikova, 1961; Nesbitt and Young, 1982; Erofeev and Tsekhovskii, 1985; Suttner and Dutta, 1986; Fedo et al., 1995). In this work, we use mostly the index CIA, which reflects weathering parameters in source areas, and diagram CIA-A-CN-K. According to (Nesbitt and Young, 1982; Fedo et al., 1995), the CIA values for clayey rocks ranging from 60 to 70 correspond to weak mostly physical weathering in provenances, values of 70-85 imply moderate chemical weathering, and values exceeding 85 indicate intense weathering with the formation of kaolinite and allite weathering profiles and laterites (residual $\mathrm{Fe}-\mathrm{Al}$ crusts).

For interpreting paleogeodynamic settings of platform and subplatform sediments, diagrams $\mathrm{K} 2 \mathrm{O} / \mathrm{Na}_{2} \mathrm{O}-\mathrm{SiO}_{2} / \mathrm{Al}_{2} \mathrm{O}_{3}$ (Maynard et al., 1982) and $\mathrm{SiO}_{2}-\mathrm{K}_{2} \mathrm{O} / \mathrm{Na}_{2} \mathrm{O}$ (Roser and Korsch, 1986) are usually used. Examples of their application are considered in (Maslov et al., 2012).

The analysis of ratios between some REE and trace elements $(\mathrm{Th} / \mathrm{Sc}, \mathrm{La} / \mathrm{Co}, \mathrm{T} / \mathrm{Co}, \mathrm{Th} / \mathrm{Cr}, \mathrm{V} / \mathrm{Ni}$, and others) characteristic of fine-grained clastic sediments is used in lithogeochemical investigations for reconstructing the composition of rocks in paleoprovenances. Such investigations are discussed in (Taylor and McLennan, 1985; McLennan, 1989; Condie and Wronkiewicz, 1990; Condie, 1993; Cullers, 1995; Interpretatsiya..., 2001; Maslov, 2005, 2012).

In this work, the parameter $\mathrm{K}_{2} \mathrm{O} / \mathrm{Al}_{2} \mathrm{O}_{3}$ is used as an indicator of proportions between lithogenic and petrogenic components in rocks. It allows the share of high$\mathrm{K} /$ petrogenic (feldspar, muscovite) and low-K/lithogenic components (kaolinite, illite) in fine-grained clastic rocks to be estimated. In mudstones and clays, the first and second varieties prevail in rocks with $\mathrm{K}_{2} \mathrm{O} / \mathrm{Al}_{2} \mathrm{O}_{3}>0.4$ and $\mathrm{K}_{2} \mathrm{O} / \mathrm{Al}_{2} \mathrm{O}_{3}<0.3$, respectively (Cox et al., 1995).

The assessment of terrigenous material transport distance is sometimes based on the analysis of the parameter of the composition of clayey rocks such as the $\mathrm{Ti} / \mathrm{Zr}$ value (Interpretatsiya..., 2001), which reflects better preservation of zircons as compared with Ti-bearing minerals during long transport and reworking of clastics.

The Mo/Mn values (the so-called coefficient of stagnation; Kholodov and Nedumov, 1991; Gavrilov et al., 2002) and some other ratios such as $\mathrm{Ni} / \mathrm{Co}$, $\mathrm{V} / \mathrm{Cr}$, and $\mathrm{V} /(\mathrm{V}+\mathrm{Ni}$ ) (Hatch and Leventhal, 1992; Jones and Manning, 1994; Rimmer, 2004) were used as indicators of redox parameters of bottom water in sedimentation basins. At the same time, practice shows that their simultaneous application frequently provides inconsistent results (Maslov et al., 2003). Our investigations reveal that, in the case of unavailability of data on Mo concentrations in clayey rocks, the redox regime in the sedimentation basin may to a certain extent be interpreted on the basis of the $\mathrm{Ni} / \mathrm{Co}$ value. 

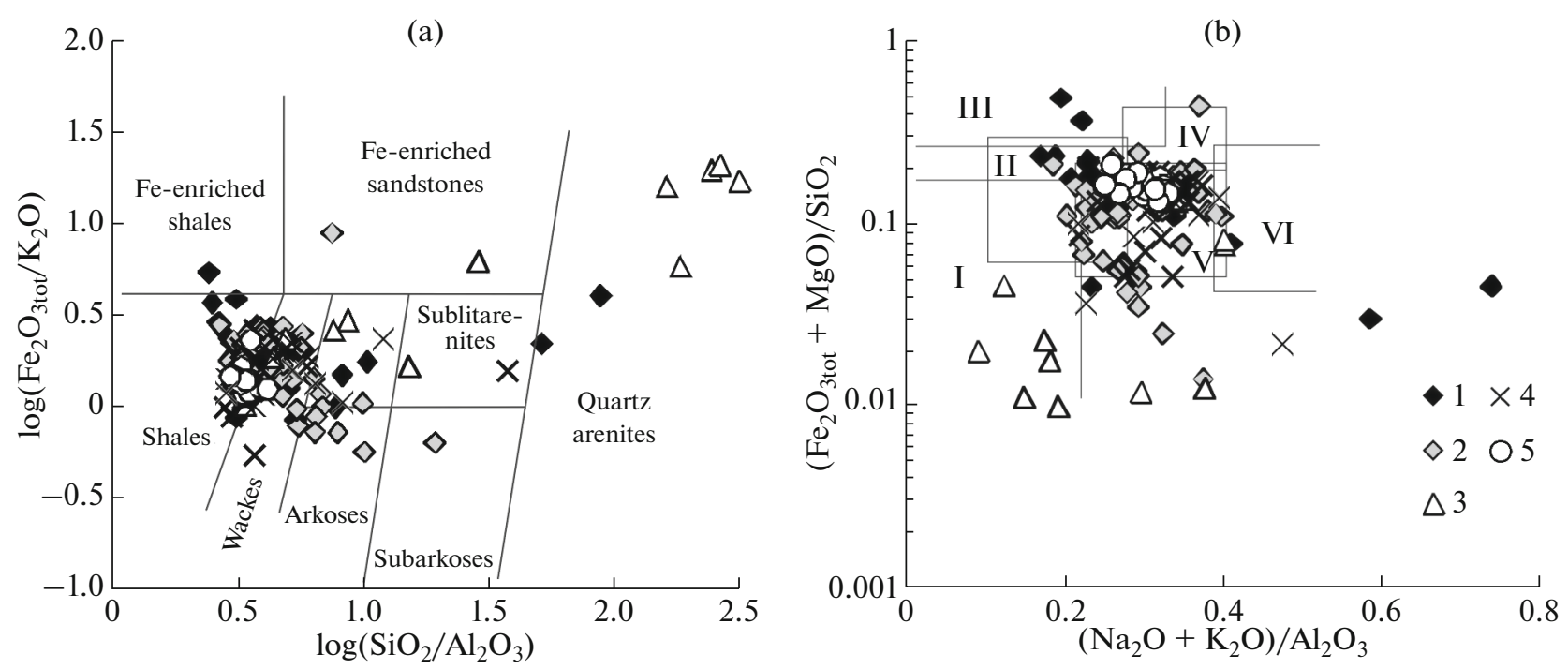

Fig. 3. Position of data points of compositions of Upper Vendian-Lower Cambrian terrigenous rocks in the northeastern Baltic monocline in classification diagrams by (a) Herron (1988) and (b) Yudovich and Ketris (2000). Formations: (1) Staraya Russa, (2) Vasileostrovskaya, (3) Voronkovo, (4) Lomonosov, (5) Siverskaya. Fig. 3b: fields of clay compositions: (I) mostly kaolinite, (II) mostly smectite with an admixture of kaolinite and hydromica, (III) mostly chlorite with an admixture of Fe-enriched illites,

(IV) chlorite-illite, (V) chlorite-smectite-illite, (VI) illite with a significant admixture of dispersed feldspar.

\section{LITHOCHEMICAL CHARACTERISTICS OF UPPER VENDIAN-LOWER CAMBRIAN ROCKS RECOVERED BY UTKINA ZAVOD, SHOTKUSA-1, AND KOROV'E-8 BOREHOLES}

The data on the whole-rock chemical composition of fine-grained detrital rocks and their geochemical properties derived from the analysis of core material from the Utkina Zavod, Shotkusa-1, and Korov'e-8 boreholes are used further for reconstructing some general features in the formation of the Upper Vendian and Lower Cambrian deposits in the northeastern part of the Baltic monocline.

On the $\log \left(\mathrm{SiO}_{2} / \mathrm{Al}_{2} \mathrm{O}_{3}\right)-\log \left(\mathrm{Fe}_{2} \mathrm{O}_{3 \text { tot }} / \mathrm{K}_{2} \mathrm{O}\right)$ classification diagram (Herron, 1988), the data points of examined terrigenous rocks are distributed mostly in fields of shales and wackes; some of them are localized in fields of arkoses and litarenites, and others (mainly characterizing rocks from the Voronkovo Formation and partly from sections of the Staraya Russa Formation) fall into the field of quartz arenites (Fig. 3a). On the $\left(\mathrm{Na}_{2} \mathrm{O}+\mathrm{K}_{2} \mathrm{O}\right) / \mathrm{Al}_{2} \mathrm{O}_{3}-\left(\mathrm{Fe}_{2} \mathrm{O}_{3 \text { tot }} / \mathrm{MgO}\right) / \mathrm{SiO}_{2}$ diagram (Yudovich and Ketris, 2000), most data points obtained for terrigenous rocks of the Valdai Group and Lontova regional stage are confined to the field $\mathrm{V}$ (chlorite-smectite-illite clays) and II (mostly smectite clays with an admixture of kaolinite and illite) (Fig. 3b). The data points characterizing rocks of the Voronkovo Formation (sandstones and siltstones with high contents of $\mathrm{SiO}_{2}$ ) occupy a specific position on this diagram as well. It may be concluded that the Upper Vendian-Lower Cambrian interval in examined sections is dominated by clayey and silty-clayey sediments characterized by a wide spectrum of com- positions: mostly chlorite-illite and smectite-kaolinite-illite clays with an admixture of detrital K-rich feldspar, Fe carbonates, and Fe minerals (goethitehematite or pyrite).

On the $\mathrm{K}_{2} \mathrm{O} / \mathrm{Na}_{2} \mathrm{O}-\mathrm{SiO}_{2} / \mathrm{Al}_{2} \mathrm{O}_{3}$ and $\mathrm{SiO}_{2}-$ $\mathrm{K}_{2} \mathrm{O} / \mathrm{Na}_{2} \mathrm{O}$ diagrams, the data points of terrigenous rocks from the Valdai Group and Lontova regional stage are concentrated mostly in fields of compositions characteristic of passive continental margin settings (Fig. 4), i.e., areas with the continental crusts very stable with respect to tectonics, which is consistent with the general geological situation. Proceeding from the aforesaid, we may assume that paleogeodynamic formation conditions of the sedimentary succession under consideration remained principally unchanged during the Late Vendian-Early Cambrian.

Inasmuch as the available analytical database contains no information on Th concentrations in clayey rocks, we applied, instead of widely used diagrams such as $\mathrm{La} / \mathrm{Sc}-\mathrm{Th} / \mathrm{Co}, \mathrm{La} / \mathrm{Sm}-\mathrm{Sc} / \mathrm{Th}, \mathrm{Sc}-\mathrm{Th} / \mathrm{Sc}$ and others, the $\mathrm{V} / \mathrm{Cr}-\mathrm{La} / \mathrm{Sc}$ and $\mathrm{Y} / \mathrm{Ni}-\mathrm{Cr} / \mathrm{V}$ diagrams based approximately on the same principles (McLennan et al., 1993). According to the $\mathrm{V} / \mathrm{Cr}-$ $\mathrm{La} / \mathrm{Sc}$ ratio, most of fine-grained detrital rocks are comparable with basic and intermediate igneous rocks and the upper continental crust (Rudnick and Gao, 2003). At the same time, the $\mathrm{La} / \mathrm{Sc}$ ratio in some samples amounts to values characteristic of granodiorites (Fig. 5a). A similar situation is also observable on the $\mathrm{Y} / \mathrm{Ni}$ - $\mathrm{Cr} / \mathrm{V}$ diagram (Fig. 5b), where most data points available for clayey rocks from different formations of the Valdai Group and Lontova regional stage are localized between data points characteristic of the aver- 

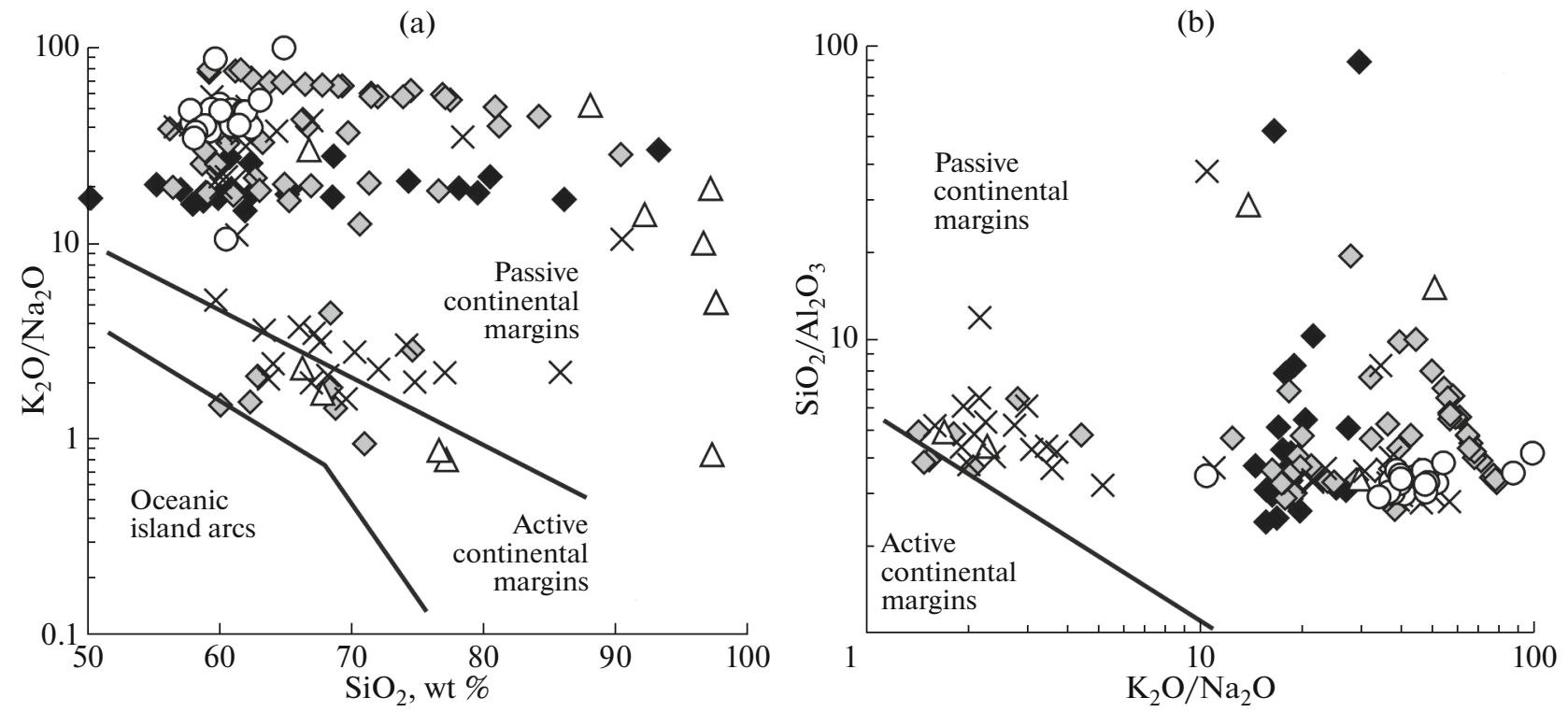

Fig. 4. Position of data points for compositions of Upper Vendian-Lower Cambrian terrigenous rocks in the northeastern Baltic monocline in classification diagrams by (a) Roser and Korsch (1986) and (b) Maynard et al. (1982). For legend, see Fig. 3.
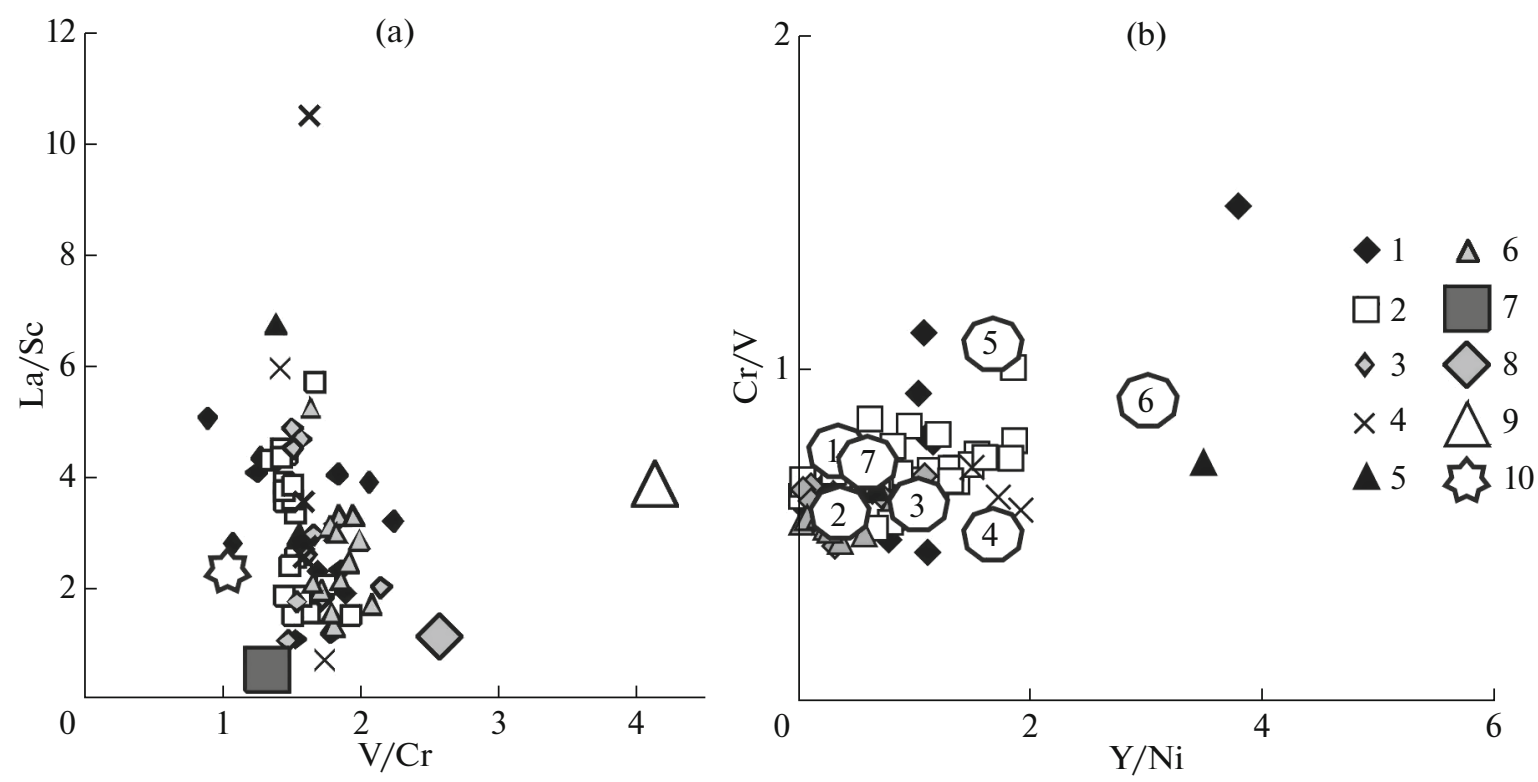

Fig. 5. Position of data points for compositions of Upper Vendian-Lower Cambrian clayey rocks in the northeastern Baltic monocline on diagrams of (a) $\mathrm{V} / \mathrm{Cr}-\mathrm{La} / \mathrm{Sc}$ and (b) $\mathrm{Y} / \mathrm{Ni}-\mathrm{Cr} / \mathrm{V}$. (1-6) Stratigraphic units: (1) Staraya Russa Formation, (2) Vasileostrovkaya Formation, (3) Voronkovo Formation, (4) Rovno regional stage, (5) Lomonosov Formation, (6) Siverskaya Formation; (7-9) average compositions of igneous rocks (after Interpretatsiya..., 2001): (7) basites, (8) diorites, (9) granodiorites; (10) average composition of the continental crust (Rudnick and Gao, 2003). In Fig. 5b, numerals (1-6) designate average compositions of igneous rocks (after Condie, 1993): (1) Early Proterozoic basalts, (2) Late Proterozoic basalts, (3) Archean TTG associations, (4) Proterozoic TTG associations, (5) Archean granitoids, (6) Proterozoic granitoids, (7) PAAS (Condie, 1993).

age composition of Early and Late Proterozoic basalts, on one hand, and Archean and Proterozoic tonalitetrondhjemite-granite associations, on the other hand. The PAAS data point is also located in this field.

Utkina Zavod borehole. Fine-grained detrital rocks of the Staraya Russa Formation in the Utkina Zavod borehole section are characterized by notable variations in values of the chemical index of alterations (81-87) and $\mathrm{K}_{2} \mathrm{O} / \mathrm{Al}_{2} \mathrm{O}_{3}(0.12-0.17)$ (Figs. 6a, 6b). High CIA values imply the involvement of variably mature material in erosion at the initial stage of transgression, while relatively low $\mathrm{K}_{2} \mathrm{O} / \mathrm{Al}_{2} \mathrm{O}_{3}$ values provide grounds for an assumption that they are characterized by a substantially lithogenic nature owing to contribution of fine-grained material from differently mature chemical weathering crusts. 


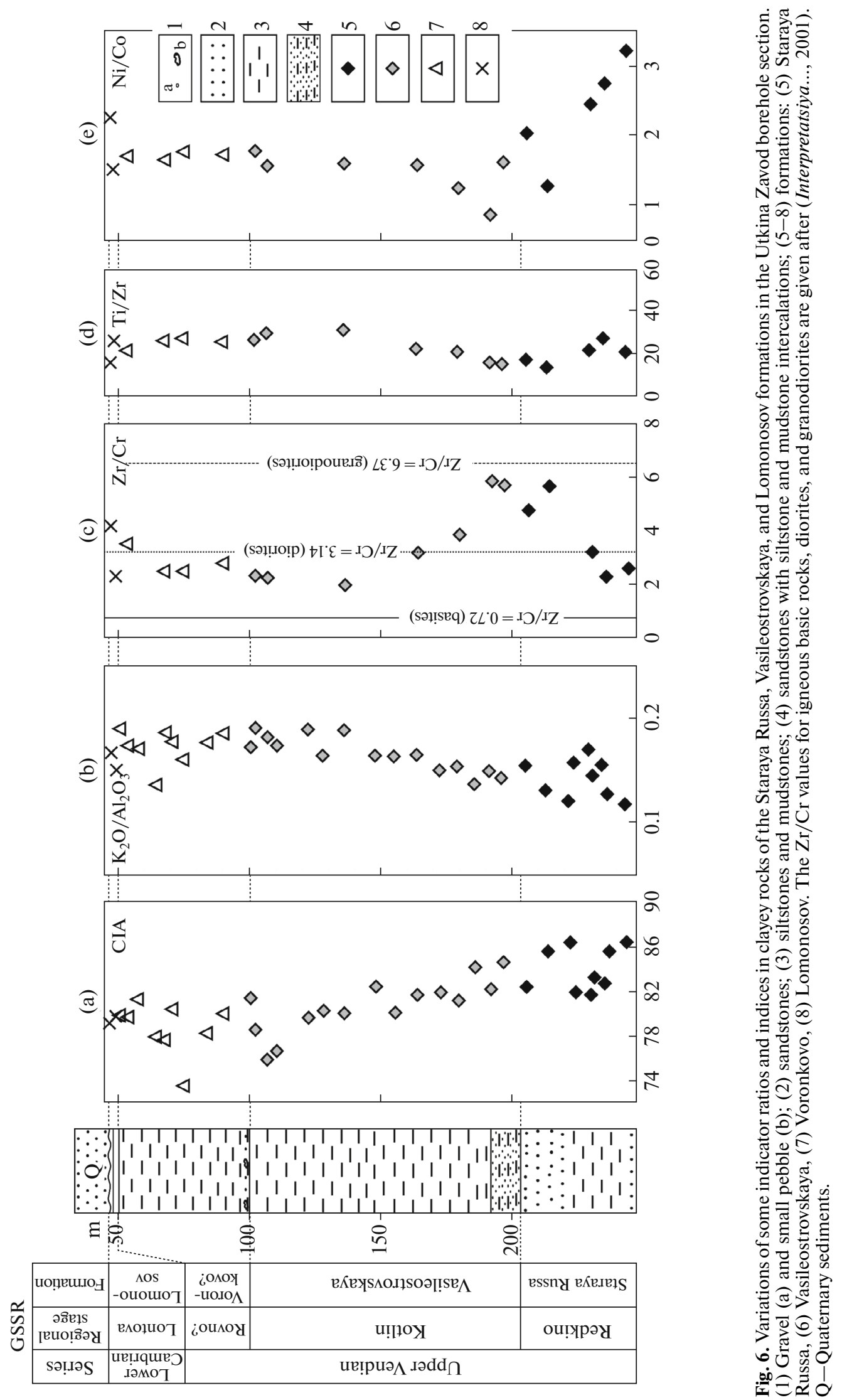


In clayey rocks of the Vasileostrovskaya Formation in the Utkina Zavod borehole section, the CIA values decrease upward, remaining within ranges characteristic of sediments deposited in humid climatic environments (70-100) up to the contact with rocks of the Lomonosov Formation. The $\mathrm{K}_{2} \mathrm{O} / \mathrm{Al}_{2} \mathrm{O}_{3}$ values through the entire 150- to 155 -m-thick section of the Vasileostrovskaya Formation never exceed 0.2, which indicates also contribution of mostly lithogenic fine-grained aluminosilicate clastics to sedimentation.

The $\mathrm{Zr} / \mathrm{Cr}$ values in clayey rocks of the overlying Staraya Russa Formation increase from $\sim 2.3$ to $\sim 5.7$ and reach 5.9 at the base of the Vasileostrovskaya Formation (Fig. 6c). At the same time, stratigraphically higher and practically through the entire section of the Vasileostrovskaya Formation, this index is usually as high as $\sim 2.0-3.5$, averaging 3.8. According to data in (Interpretatsiya..., 2001), the average $\mathrm{Zr} / \mathrm{Cr}$ value in granodiorites is $\sim 6.4$ and is slightly lower in diorites $(\sim 3.1)$ an even lower in basic igneous rocks $(\sim 0.7)$. On the assumption that the $\mathrm{Zr}$ and $\mathrm{Cr}$ ratios characteristic of igneous rocks are preserved without substantial changes in fine-grained detrital rocks formed by their clastics, it may be concluded that, during the formation of practically the entire Staraya Russa-Vasileostrovskaya sedimentary succession recovered by Utkina Zavod borehole, the paleoprovenance was dominated by basic and intermediate rocks. The appearance of granodiorite rocks in the source area may be assumed for the end of the Staraya Russa and initial Vasileostrovskaya time. This is also confirmed by the distribution of data points of mudstones and clays of the Valdai Group and Lontova regional stage on the $\mathrm{V} / \mathrm{Cr}-\mathrm{La} / \mathrm{Sc}$ and $\mathrm{V} / \mathrm{Ni}-\mathrm{Zr} / \mathrm{Cr}$ diagrams.

$\mathrm{The} \mathrm{Ti} / \mathrm{Zr}$ ratio in Upper Vendian clayey rocks of the borehole section in question varies from 14 to 21 , although no significant changes in its values are observable up the section (Fig. 6d). This fact implies the absence of substantial variations in the remoteness of the source area which yielded detrital material to the Utkina Zavod borehole area during the entire Staraya Russa-Vasileostrovskaya time.

Clayey rocks from the upper part of the Staraya Russa Formation and entire Vasileostrovskaya Formation are also characterized by absence of any significant variations in the $\mathrm{Ni} / \mathrm{Co}$ values, an indicator of redox conditions in the bottom water layer of the sedimentation basin (0.9-3.2, Fig. 6e), which suggests accumulation of sediments in aerated oxidized settings.

Shotkusa-1 borehole. This borehole recovered the section of Upper Vendian rocks similar in its structure to the Utkina Zavod borehole section. The section of Shotkusa-1 borehole demonstrates differently directed variation in the CIA values (Fig. 7a) in the interval of 267-217 m corresponding to the Staraya Russa Formation, although as a whole they never exceed the threshold value of 70, which separates sediments of the arid/nival climate, on one hand, and humid climate, on the other hand (Nesbitt and Young, 1982). Thus, as in the Utkina Zavod borehole, the section of the Staraya Russa Formation is composed of sediments relatively mature with respect to their lithochemistry, and observable CIA variations through the latter are determined by irregular development of transgression and erosion of sedimentary material variably transformed by weathering processes. Clayey rocks of the Vasileostrovskaya Formation exhibit no such notable variations in the CIA values (73-78).

The behavior of the $\mathrm{K}_{2} \mathrm{O} / \mathrm{Al}_{2} \mathrm{O}_{3}$ ratio is inverse relative to CIA variations (Fig. $7 \mathrm{~b}$ ). This likely reflects also the main tendency in the formation of the Staraya Russa section: variations in the degree of sedimentary material weathering in paleoprovenances at the initial transgressive development stage of the Late Vendian sedimentation basin with the increased/decreased share of detrital K-rich minerals (feldspar, muscovite) and then strengthened weathering with the growth in the role of kaolinite at the regressive stage of the Redkino sedimentation cycle.

The values of $\mathrm{Zr} / \mathrm{Cr}$ in clayey rocks of the Staraya Russa Formation (1.1-5.2) are comparable with its values in basic and intermediate igneous rocks (Fig. 7c) except for Sample 1-30 from the depth of $216.5 \mathrm{~m}$, where the parameter $\mathrm{Zr} / \mathrm{Cr}$ reaches 8.4, although the latter is characteristic of quartzose sandstone, not clayey rock.

In the entire sections of the Vasileostrovskaya and Staraya Russa a distinct variations in $\mathrm{Ti} / \mathrm{Zr}$ ratio were not recorded (Fig. 7d). This is probably the evidence that there were no any significant rearrangements of transportation ways of the clastics during the rock sedimentation.

The entire examined section demonstrates also the prevalence of Mo/Mn values below 0.005 (Fig. 7e). This implies deposition of primary sediments in aerated settings. Only several samples from some levels yielded $\mathrm{Mo} / \mathrm{Mn}$ values of $0.01-0.17$ characteristic of sediments deposited in dysaerobic conditions.

The onset of the Vasieostrovskaya cycle was marked by accumulation of quartz and mica-quartz sandstones (interval of 216.6-195.0 m) with abundant detrital K-rich feldspar in shallow-water marine or, probably, aerial settings, which is reflected in elevated $\mathrm{K}_{2} \mathrm{O} / \mathrm{Al}_{2} \mathrm{O}_{3}$ values (up to 0.5 ). The lithochemical parameters of silty-clayey rocks in the higher part of the Vasileostrovskaya Formation in the Shotkusa-1 borehole (interval of 197-102 m) indicate relatively stable depositional environments. The sedimentation area representing a shallow-water epicontinental marine basin at that time received mixed (lithogenic and petrogenic) clayey material from weathering crusts of the platformal type, which were formed under moderately humid climate condition.

As a whole, tendencies of changes in lithochemical parameters of silty-clayey sediments of the Staraya 


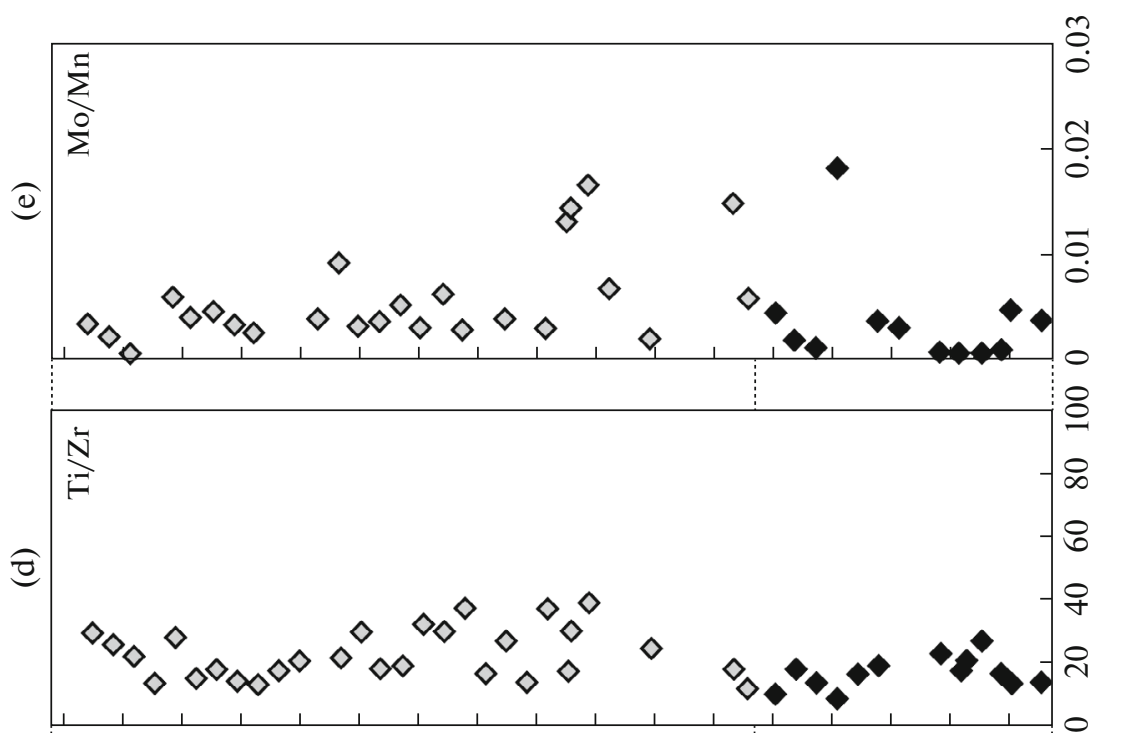


Russa and Vasileostrovskaya formations defined for the Shotkusa-1 borehole section are comparable with their counterparts in the Utkina Zavod borehole. Taking into consideration the distance between these boreholes (over $120 \mathrm{~km}$ ), some differences in variations of lithochemical indices may be determined by local peculiarities in accumulation of sediments of the Redkino and Kotlin regional stages with generally retained sedimentation patterns: prevalence of feldspar-kaolinite-illite material transported into the basin from chemical weathering crusts.

Korov'e-8 borehole. Variations in the chemical composition of silty-clayey rocks from the uppermost part of the Vasileostrovskaya Formation as well as the Voronkovo, Lomonosov, and Siverskaya formations in the Korov'e- 8 borehole display some peculiar features. For example, the succession presumably belonging to the Vasileostrovskaya (interval of 262$232 \mathrm{~m}$ ) and Voronkovo (interval 232-213 m) formations demonstrates some growth of CIA values up the section from $\sim 77$ to $79-80$ and an insignificant decrease in $\mathrm{K}_{2} \mathrm{O}$ content (Figs. 8a, 8b). Such a trend likely reflects insignificant intensification of rock weathering in source areas and recycling of clayey material against the background of slight regression in the shallow-water basin.

The higher part of the section (Lomonosov Formation, interval of $213-197 \mathrm{~m}$ ) exhibits a gradual decrease in CIA values for silty-clayey rocks and some increase in $\mathrm{K}_{2} \mathrm{O} / \mathrm{Al}_{2} \mathrm{O}_{3}$ values (Fig. 8b). It may be assumed that these peculiarities in behavior of the parameters under consideration reflect the beginning of a new, Cambrian, stage in the basin evolution (Lontova (Mens and Pirrus, 1986), or Lomonosov transgression) accompanied by the replacement of supralittoral facies by slightly more "offshore" littoral and sublittoral sediments, which became the most widespread at the beginning of accumulation of the Lower Cambrian Siverskaya Formation.

The Lomonosov sedimentation cycle was accompanied by the weakened influence of chemical weathering in source areas (Baltic Shield). This resulted in the gradual replacement of substantially lithogenic chlorite-kaolinite-illite associations of clay minerals by mixed lithogenic-petrogenic varieties with the increased share of kaolinite and increased role of detrital K-rich feldspar.

The subsequent stage retained generally this trend: the section of the Siverskaya Formation is dominated by silty-clayey rocks with low cyclically varying CIA values, but elevated $(0.3-0.35) \mathrm{K}_{2} \mathrm{O} / \mathrm{Al}_{2} \mathrm{O}_{3}$ values. Such properties reflect both generally weak weathering in source areas despite the presence of kaolinite in rock and prevalence of physical weathering against the background of relatively high sedimentation rates and depositional environments of the moderately deep $(n \times 10-150 \mathrm{~m})$ marine epicontinental basin. The prevalence of physical weathering in source areas during accumulation of silty-clayey sediments of the Siverskaya Formation is also evident from their mineral composition.

The tendencies in question are also distinct on the CIA-A-CN-K diagrams (Fig. 9), which demonstrate the replacement of K-rich practically $\mathrm{Na}$-free rocks of the Staraya Russa Formation (Utkina Zavod and Shotkusa-1 boreholes) by slightly less mature material, although slightly more enriched in $\mathrm{Na}$, of the Vasileostrovskaya Formation and stabilization of compositions of Lower Cambrian aleuropelites in the ranges of CIA values characteristic of litho-petrogenic sediments of areas with moderate chemical weathering. The insignificant range of CIA variations in this succession implies (1) "stable" influence of the main source (weathering crusts developed after mostly Riphean basement of the Baltic Shield) and (2) contribution of erosional products of rocks from the Riphean Priozersk Formation, which are relatively mature, K-enriched, and recycled, to the formation of sedimentary rocks.

The analysis of the $\mathrm{Nd}$ isotope composition of fine-grained rocks from the Valdai-Baltic sedimentary succession reveals that the model $\mathrm{T}_{\mathrm{Nd}}(\mathrm{DM})$ age of hypothetical protoliths of sediments varies insignificantly from 2.3-2.0 Ga in the Staraya Russa Formation and basal part of the Vasileostrovskaya Formation (Utkina Zavod borehole) to $1.7 \mathrm{Ga}$ in the uppermost part of the latter (or basal part of the Voronkovo Formation) in the Korov'e- 8 borehole section and Lomonosov Formation of the Utkina Zavod borehole. In Lower Cambrian clayey sediments of the Lontova Formation (analog of the Siverskaya Formation), the model $\mathrm{T}_{\mathrm{Nd}}(\mathrm{DM})$ age values are "rejuvenated" up to 1.6-1.7 Ga (Gorokhov et al., 2007). This is also indicative of the prevalence of Paleoproterozoic substrates in source areas and insignificant contribution of Riphean-Vendian sources.

The $\mathrm{Zr} / \mathrm{Cr}$ values in clayey rocks of the Vasileostrovskaya, Lomonosov, and Siverskaya formations vary from 0.35 to $\sim 2.0$. This implies contribution of eroded basites and diorites to their compositions (Fig. 8c). Variations of this parameter in clayey rocks of the Voronkovo Formation are slightly more notable (0.35-3.7), which, however, provides no evidence for any cardinal changes in the composition of rocks in source areas. Clayey rocks from the uppermost part of the Vasileostrovskaya Formation as well as from the Voronkovo and Lomonosov formations are characterized by variations in the $\mathrm{Ti} / \mathrm{Zr}$ parameter within a range of $\sim 10-50$, and in clays from the Siverskaya Formation, this parameter ranges from 9 to 70 (Fig. 8d).

Variations in values of parameters indicating redox environments show that Vendian clayey sediments recovered by Korov'e- 8 borehole were largely deposited in oxidizing settings (Fig. 8d). Only for some intervals of the section with dominant gray-colored rocks may it be assumed that they were formed in slightly oxygen-deficient environments (dysoxic 


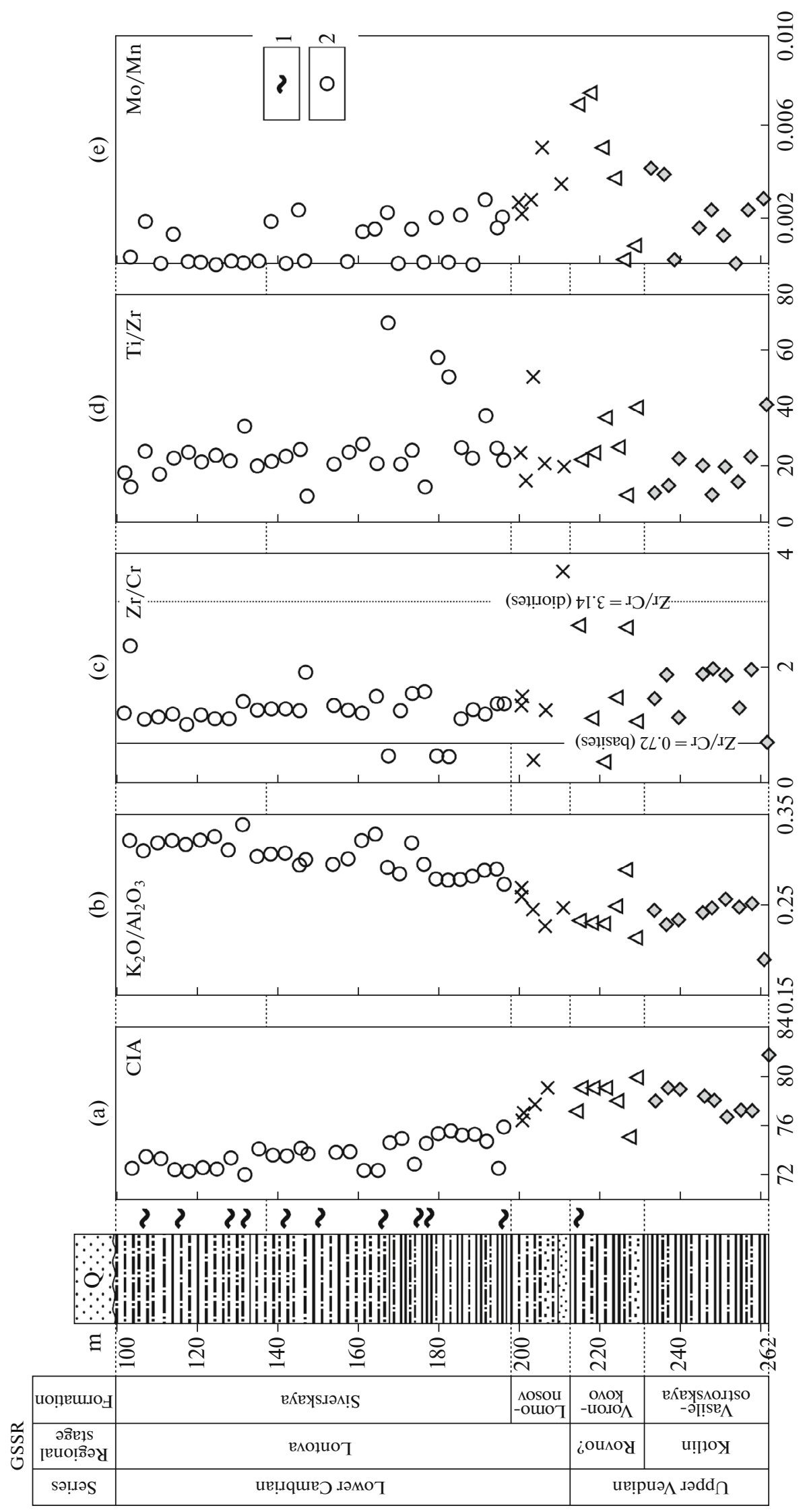



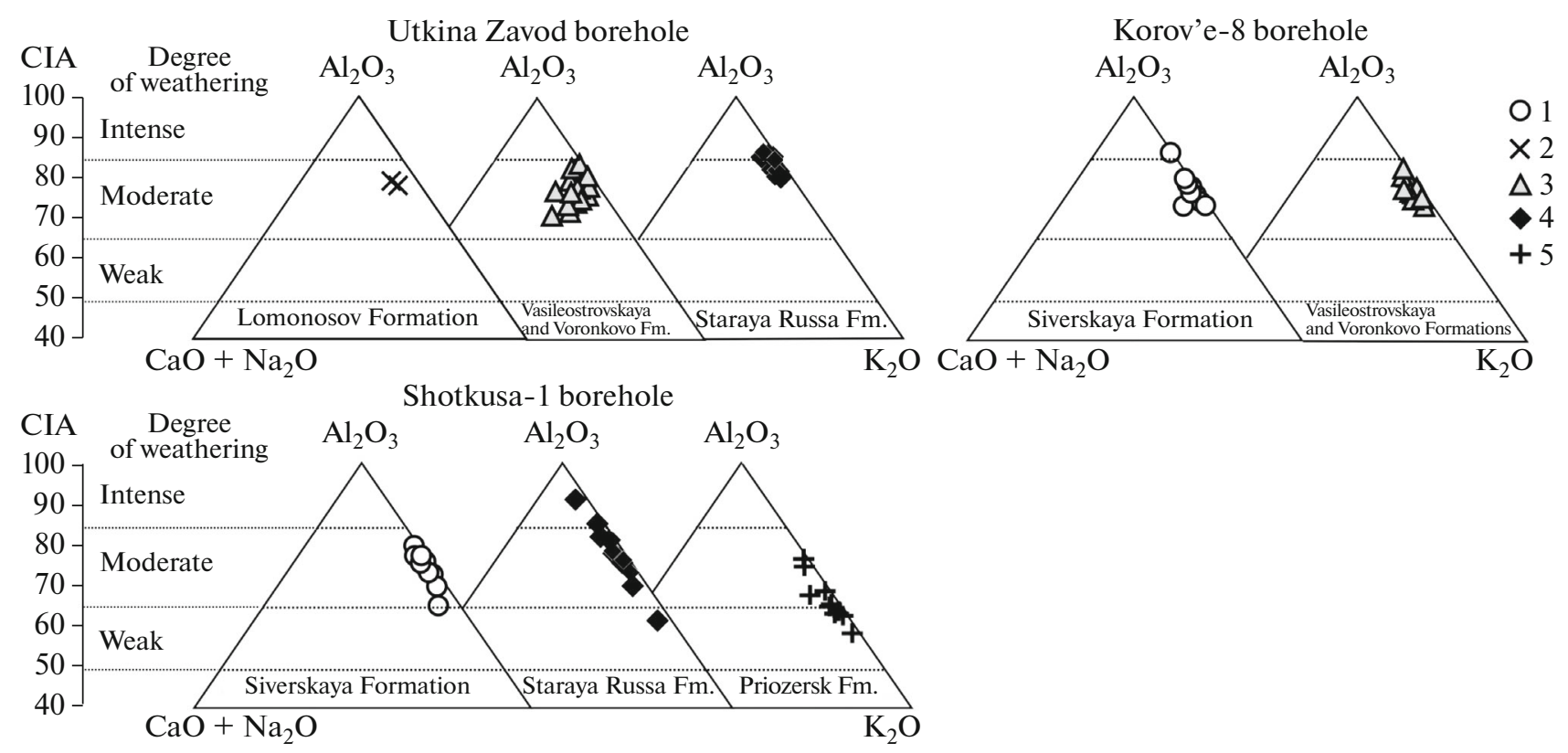

Fig. 9. CIA-A-CN-K diagrams for Upper Vendian and Lower Cambrian rocks of the northeastern Baltic monocline. Formations: (1) Siverskaya, (2) Lomonosov, (3) Vasileostrovskaya and Voronkovo, (4) Staraya Russa, (5) Priozersk.

facies), which is evident only from the Mo/Mn value. The same is true of the Lomonosov level of the Lower Cambrian section. As a whole, it may be stated that Upper Vendian deposits recovered by Korov'e- 8 borehole accumulated in a substantially better aerated basin as compared with sediments of the Vasileostrovskaya Formation in the Shotkusa-1 borehole section and deposits of the Staraya Russa and Vasileostrovskaya formations in the Utkina Zavod borehole.

\section{DISCUSSION AND CONCLUSIONS}

On the basis of lithological, mineralogical, and lithochemical data, the sedimentary successions recovered in the northeastern part of the Baltic monocline by the Utkina Zavod, Shotkusa-1, and Korov'e-8 boreholes may be divided into three sedimentation cycles corresponding to (1) the Upper Vendian Redkino regional stage (Staraya Russa Formation), (2) the Upper Vendian Kotlin (Vasileostrovskaya Formation) and Rovno? (Voronkovo Formation) regional stages, and (3) the Lomonosov and Siverskaya formations of the Lower Cambrian Baltic Group. Lithological boundaries between these cycles in the examined sections are usually vague except for western areas of the study region, where they are partly unconformable with erosional surfaces at the base (Staraya Russa and Vasileostrovskaya formations in the Utkina Zavod borehole section). In the Shotkusa-1 borehole, the Staraya Russa Formation overlies unconformably Lower(?) Riphean sandstones. The base of the Vasileostrovskaya Formation (Utkina Zavod and Shotkusa-1 boreholes) is also marked by distinct lithological changes, although without erosional features. This level is characterized by the prevalence of sandy and silty rocks (lower subformation or "Gdov Sandstones"). The Cambrian part of the section is also characterized by notably coarser terrigenous sediments at the base of the Lomonosov Formation.

As was repeatedly noted (Mens and Pirrus, 1971; Paleogeografiya ..., 1980; Sokolov and Fedonkin, 1985; Hagen-Thorn, 2011, 2012), the upper boundaries of these cycles in sections located east and southeast of the Lomonosov-Gdov line are frequently gradual. In the Korov'e- 8 borehole section, such relations are characteristic of the contact between the Lomonosov and Siverskaya formations and, likely, between the Vasileostrovskaya Formation and overlying strata of the Voronkovo Formation of the Rovno regional stage (interval of 232-213 m).

In this situation, of certain significance are the reconnaissance geochronological data on detrital zircons of the Valdai and Baltic groups (Ivleva et al., 2016). The rocks from the uppermost part of the Staraya Russa Formation (Utkina Zavod borehole, Sample T36, depth $203 \mathrm{~m}$ ) are practically barren of zircon grains with ages younger than $1.5 \mathrm{Ga}$, being dominated by Paleoproterozic and Mesoproterozoic zircons accompanied by Archean specimens (3-4\%). In contrast, the population of detrital zircons extracted from sandstones of the Voronkovo Formation in the Korov'e- 8 borehole section (Sample 8-16, depth $232 \mathrm{~m}$ ) includes Neoproterozoic (36\% of the population) and Vendian-Cambrian grains $(\sim 9 \%)$ in addition to Archean-Mesoproterozoic specimens (Ivleva et al., 2016). The age of five concordant zircon grains belonging to the youngest 
Results of $\mathrm{U}-\mathrm{Pb}$ dating of zircons from Sample 8-16 (Korov'e-8 borehole) (ages corresponding to the youngest population of zircons are given)

\begin{tabular}{|c|c|c|c|c|c|c|c|c|c|c|c|c|}
\hline \multirow{2}{*}{$\begin{array}{c}\text { Analysis } \\
\text { number }\end{array}$} & \multirow{2}{*}{$\begin{array}{c}\mathrm{U}, \\
\mathrm{ppm}\end{array}$} & \multirow{2}{*}{$\begin{array}{l}\text { Th, } \\
\text { ppm }\end{array}$} & \multirow{2}{*}{$\mathrm{U} / \mathrm{Th}$} & \multicolumn{4}{|c|}{ Isotopic ratios } & \multirow{2}{*}{$\begin{array}{c}\text { Correla- } \\
\text { tion } \\
\text { error }\end{array}$} & \multicolumn{4}{|c|}{ Age, Ma } \\
\hline & & & & ${ }^{207} \mathrm{~Pb} /{ }^{235} \mathrm{U}$ & $2 \sigma$ & ${ }^{206} \mathrm{~Pb} /{ }^{238} \mathrm{U}$ & $2 \sigma$ & & ${ }^{206} \mathrm{~Pb} /{ }^{238} \mathrm{U}$ & $2 \sigma$ & ${ }^{207} \mathrm{~Pb} /{ }^{206} \mathrm{~Pb}$ & $2 \sigma$ \\
\hline 8-16_42.FIN2 & 175 & 157.9 & 1.108 & 0.66 & 0.013 & 0.0826 & 0.0013 & 0.412 & 511.5 & 8 & 536 & 45 \\
\hline 8-16_12.FIN2 & 307.9 & 232.2 & 1.326 & 0.677 & 0.01 & 0.083 & 0.0014 & 0.487 & 514 & 8.3 & 607 & 36 \\
\hline 8-16_14.FIN2 & 170.9 & 210.2 & 0.813 & 0.698 & 0.016 & 0.086 & 0.0019 & 0.422 & 532 & 11 & 573 & 62 \\
\hline 8-16_30.FIN2 & 355.4 & 381.7 & 0.931 & 0.6918 & 0.0081 & 0.08643 & 0.00081 & 0.306 & 534.4 & 4.8 & 545 & 31 \\
\hline 8-16_33.FIN2 & 94.4 & 115.4 & 0.818 & 0.702 & 0.014 & 0.0865 & 0.0012 & 0.487 & 534.6 & 6.9 & 590 & 40 \\
\hline 8-16_36.FIN2 & 79.1 & 93.2 & 0.849 & 0.71 & 0.022 & 0.0873 & 0.0018 & 0.050 & 540 & 11 & 569 & 80 \\
\hline 8-16_32.FIN2 & 75.8 & 102.6 & 0.739 & 0.712 & 0.02 & 0.0881 & 0.0015 & 0.090 & 545.8 & 9 & 541 & 67 \\
\hline
\end{tabular}

population from the interval of $232-231 \mathrm{~m}$ in the Korov'e- 8 borehole (Samples 8-16) varies from 546 to $532 \mathrm{Ma}$ (table), which allows the whole interval of 232-213 $\mathrm{m}$ to be attributed to the Upper Vendian Voronkovo Formation, although its belonging to Lower Cambrian Lontova (Lomonosov) level cannot be ruled out.

With consideration for lithological reconstructions, the mineral and chemical composition of rocks allows the following schematic correlation of examined sections to be proposed (Fig. 10). Brasier (1992) was the first to pay attention to insufficient paleontological data on age of Upper Vendian layers (age interval of 550 to $540 \mathrm{Ma}$ ). This author proposed the term "Kotlin crisis" for this phenomenon. In his opinion, the Kotlin crisis could be an important link in a chain of events which led to the "Cambrian biodiversity outburst." The disappearance of tribrachiomorphs, dickinsoniomorphs, and bilateromorphs, which was followed by the appearance of biologically controlled mineralization and burrowing organisms, is considered as a peculiar feature of this crisis (Grazhdankin, 2014).

Several scenarios of probable succession of events which preceded and to some extent determined the Kotlin crisis were proposed. The first of them is a "feeding-stimulating scenario" (Brasier, 1992; Brasier and Lindsay, 2001), according to which the crisis resulted from the growth of nutrient contents in a relatively deep water basin with anoxic conditions against the background of global sea regression ("Kotlin regression") with the subsequent transgression, which was responsible for the influx of nutrients onto shallow-water shelves. It was assumed that these events led to cardinal changes in marine ecosystems and accelerated evolution of multicellular organisms. The alternative scenarios suggest geochemical perturbations during the Ediacaran (Vendian) time (Butterfield, 2011; Lenton et al., 2014) or biotic replacement of the Ediacaran biota by ecosystems of the Cambrian type (Darroch et al., 2015).

Recent investigations brought new detailed data on the succession of the Redkino, Kotlin, Rovno?, and Lontova assemblages of fossil organisms in both the
Baltic monocline (Golubkova et al., 2016) and the Mezen syneclise (Vorob'eva et al., 2009; Golubkova et al., 2015) regions. These data might make it possible to specify the local and regional stratigraphic scales and reveal the main paleoecological trends in the evolution of the Late Vendian-Early Cambrian microbiotas on the East European Platform.

Noting that the terminal Vendian represents a geocratic epoch for several ancient platforms, including the East European Platform, Vorob'eva and Petrov (2014, pp. 89, 91) put forward an idea that "a substantial paleogeographic role belonged to continental basins at that time: from desalinated basins of relatively high paleolatitudes with terrigenous sedimentation to low-latitude basins with mixed terrigenous-carbonate and evaporitic sedimentation. It is likely that the large reorganization of ecosystems and the associated drastic decrease in taxonomic diversity observed from the beginning of the Kotlin Age ... could have resulted from "continentalization" of paleoenvironments in basins of that time. Such a reorganization affected to a significant extent calm mainly relatively deep settings of muddy sedimentation to provide vacant ecological niches in the corresponding time interval. These niches were quickly colonized by the most primitive phototrophic cyanobacterial communities, and their necromass served as nutrient for vendomiceses."

The Upper Vendian-Lower Cambrian sections of the northeastern Baltic monocline represent a very suitable object for testing views on geochemical perturbations during the Ediacaran (Vendian) time (Butterfield, 2011; Lenton et al., 2014) as a cause of the Kotlin crisis. The available sedimentary succession offers the opportunity to assess changes in the formation of deposits both through the time interval with the Kotlin crisis (Vasileostrovskaya and Voronkovo formations) and immediately after it. The best result may be achieved by comparing lithogeochemical parameters of clayey rocks recovered by the Shotkusa- 1 and Korov'e- 8 boreholes.

Variations in paleoclimatic indicators (changes in CIA values). Clayey rocks of the Staraya Russa For- 


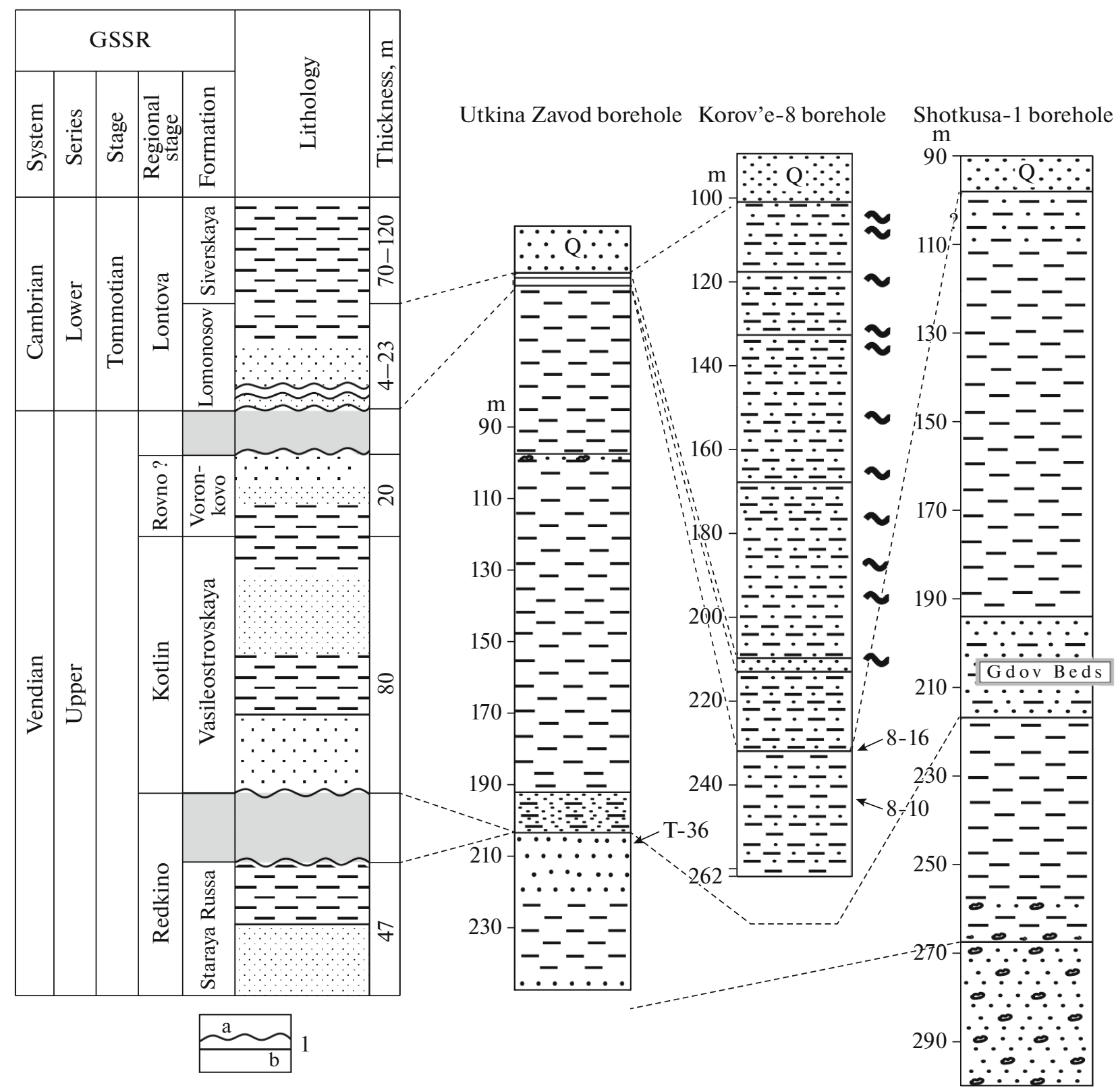

Fig. 10. Schematic correlation of investigated Upper Vendian-Lower Cambrian sections of the northeastern Baltic monocline. (1) Stratigraphic unconformity and hiatuses (a) and conformable boundary (b). For other symbols, see Figs. 2, 6-8. Arrows show position of samples dated by the U-Pb zircon method and their numbers.

mation demonstrate more or less significant variations in values of this parameter (from $\sim 68$ to 80 ). Through the entire overlying section, the CIA values vary within a range of 70-80 (with a vague tendency for its decrease up the section), which indicates approximately uniform (moderately humid) climatic conditions during accumulation of pre-Kotlin, Kotlin, and post-Kotlin deposits.

According to (Maslov et al., 2013), clayey rocks of the Kotlin level recovered in the southeastern White Sea region (Tuchkino-1000 borehole) are characterized by insignificant growth of the CIA value up the section. Variations in the CIA values in this section are 67-75 for rocks of the Kotlin level and 63-72 for preKotlin deposits. In the Vychegda trough (Kel'tma-1 borehole), values of the chemical index through the entire Upper Vendian section vary mostly from 62 to 72. In the composite Vendian section on the western slope of the Middle Urals, clayey rocks of the Chernokamensk Formation corresponding to the Belomorian and Kotlin regional stages (Grazhdankin and Maslov, 2015) demonstrate no principal variations in the CIA value, which is consistent with the behavior of 
this parameter in the Upper Vendian-Lower Cambrian section of the northeastern Baltic monocline.

Ratios between lithogenic and petrogenic components in clayey rocks (variations in $\mathrm{K}_{2} \mathrm{O} / \mathrm{Al}_{2} \mathrm{O}_{3}$ values). Pre-Kotlin and Kotlin clayey rocks are characterized by the prevalence of lithogenic material in their composition (the average $\mathrm{K}_{2} \mathrm{O} / \mathrm{Al}_{2} \mathrm{O}_{3}$ value does not exceed 0.28 ). The section of the Lomonosov and Siverskaya formations exhibits the tendency for the visually insignificant growth of this parameter from 0.22 to 0.34 , although its value in this interval is approximately the same as that in underlying rocks (0.29), which provides no grounds for the assumption that the influx of petrogenic material into the sedimentation basin sharply increased in the initial Cambrian.

In the Tuchkino-1000 borehole (southeastern White Sea region, White Sea-Kuloi Plateau), clayey rocks of the Kotlin level (Erga Formation) are characterized by $\mathrm{K}_{2} \mathrm{O} / \mathrm{Al}_{2} \mathrm{O}_{3}$ variations in a range of $0.24-0.30$, while values of this parameter in underlying deposits vary mostly within a range of $0.20-0.26$ (Maslov et al., 2013). To the contrary, in the Kel'tma-1 borehole (Vychegda Trough), no distinct tendencies in changes of $\mathrm{K}_{2} \mathrm{O} / \mathrm{Al}_{2} \mathrm{O}_{3}$ values are observable through the entire Upper Vendian section. The same is true of clayey rocks in the Chernokamensk Formation of the KvarkushKamennogork meganticlinorium (western slope of the Middle Urals). According to $\mathrm{U}-\mathrm{Pb}$ dating of zircons from volcanic tuffs occurring at the base of the Chernokamenskaya Formation, its age is $557 \pm 13 \mathrm{Ma}$ (Ronkin et al., 2006). Thus, no principal changes in the main parameters $\left(\mathrm{K}_{2} \mathrm{O} / \mathrm{Al}_{2} \mathrm{O}_{3}\right.$ and CIA $)$ are revealed through the Upper Vendian-Lower Cambrian interval in the Middle Urals, Mezen Depression, or northwestern Baltic monocline except for the southeastern part of the White Sea region.

Composition of rocks in source areas $(\mathrm{Zr} / \mathrm{Cr}$ variations and data on $\mathrm{U}-\mathrm{Pb}$ ages of detrital zircon from sandstones). Practically through the entire investigated Upper Vendian-Lower Cambrian interval, the $\mathrm{Zr} / \mathrm{Cr}$ values vary within a range of $0.5-4.0$, which probably indicates the prevalence of the homogeneous rock complex in the source area. At the same time, the distribution of $\mathrm{U}-\mathrm{Pb}$ isotopic ages obtained for detrital zircons from the Upper Vendian and Lower Cambrian sections of the northeastern Baltic monocline is substantially variable. In Upper Vendian sandstones, the dominant role belongs to the Paleoproterozoic and, to a lesser extent, Mesoproterozoic zircons. Moreover, different levels of the Upper Vendian section are characterized by slightly different distribution spectra of detrital zircon ages, which implies the presence of a heterogeneous association of parental rocks in source areas. The peaks of zircon ages characteristic of Upper Vendian sandstones correlate with ages of igneous and metamorphic rocks of the basement $(>1.5 \mathrm{Ga})$ in the southern part of the Baltic shield (Rannii..., 2005). In Lower Cambrian sandstones, the dominant role belongs to zircon grains with Mesoproterozoic ages, Neoproterozoic grains are subordinate, and Early Cambrian zircons are represented by single grains. It is known that no notable Neoproterozoic and Early Cambrian magmatism is registered on the Baltic Shield (Rannii..., 2005), although its products are widespread in the Timan-Pechora region (Kuznetsov et al., 2010; etc.); therefore, it is quite possible that precisely the latter yielded such detrital zircons in the initial Cambrian (Ivleva et al., 2016).

The presence of young zircon generations in Lower Cambrian sediments is consistent with the "rejuvenation" trend of $\mathrm{Nd}$ model ages of the Lontova clays (analog of the Siverskaya Formation) in the northwestern part of the East European Platform. According to $\mathrm{Rb}-\mathrm{Sr}$ and $\mathrm{Sm}-\mathrm{Nd}$ systematics of detrital illites, eroded material could be the Late Riphean in age: 790-720 Ma (Gorokhov et al., 2007). The sediments of such age could have been deposited owing to weathering of inliers of the platform basement and Riphean volcanogenic sedimentary rocks constituting surrounding structures (Maslov et al., 2013). It should be noted that the absence of deposits dated back to 800-600 Ma recorded in sedimentary basins of the northeastern (Mezen syneclise; Golubkova et al., 2015) and eastern (Bashkir meganticlinorium and VolgaUrals region; Kuznetsov et al., 2003; Zaitseva et al., 2008; Maslov, 2012) framing of the East European Platform indicates indirectly a high probability of such erosion. Moreover, eroded material could have been transported also in the westerly direction owing to geodynamic evolution of the conjugate orogenic structure (Becker, 1968; Maslov and Podkovyrov, 2010).

Remoteness of source areas ( $\mathrm{Ti} / \mathrm{Zr}$ variations). The average $\mathrm{Ti} / \mathrm{Zr}$ value for clayey rocks is estimated to be $20 \pm 7$ in the Staraya Russa-Voronkovo interval and $26 \pm 12$ in the Lomonosov-Siverskaya interval. This indicates the absence of a significant trend of changes in the distance of clastic material transport during the pre-Kotlin, Kotlin, and post-Kotlin time in the northeastern part of the Baltic monocline.

Redox conditions in sedimentation basins. The values of the stagnation coefficient (Mo/Mn) in Upper Vendian-Lower Cambrian fine-grained detrital rocks of the region under consideration are usually below 0.005; only at some levels (uppermost part of the Staraya Russa Formation, basal and middle parts of the Vasileostrovskaya Formation) does the Mo/Mn ratio exceed this value. Most likely, pre-Kotlin, Kotlin, and post-Kotlin sediments in the northeastern part of the Baltic monocline were deposited in aerated environments.

Summing up the aforesaid, one may conclude that no traces/features of any significant lithochemical changes except for some variations in intensity of weathering in source areas and changes in directions of clastic material transport with the appearance of an eastern "young" Late Vendian-Early Cambrian source 
or local "Late Riphean" recycled source are observable in the Upper Vendian-Lower Cambrian sedimentary successions of the eastern Baltic monocline.

These facts indicate that the known peculiarity of Kotlin biocoenoses (Burzin, 1996) is independent of lithofacies and lithogeochemical properties of constituting sediments and is determined likely by more global factors of the biosphere evolution in the Late Vendian. Recently, foreign authors have arrived at the same conclusion, considering that the "first mass extinction of complex organisms" was to a significant extent determined by evolutionary innovations, reorganizations of ecosystems, and biological interrelations, in addition to changes in paleosettings (Laflamme et al., 2013; Darroch et al., 2015; etc.).

\section{ACKNOWLEDGMENTS}

We are grateful to the administration of OOO PKGE Nedra for the possibility to sample core material from the Korov'e- 8 and Shotkusa boreholes and analytical data, and personally to A.S. Yanovskii and S.D. Shvedov for consulting and discussions of the results obtained. We thank also V.P. Kovach for his help in analyzing the $\mathrm{Nd}$ isotope composition in clayey rocks and E.Yu. Golubkova for discussion of the paleontological record in Vendian successions.

This work was supported by the Russian Foundation for Basic Research, project nos. 14-05-00415, 14-0500813, 15-05-01512, and 15-35-20591.

\section{Reviewers P.Yu. Petrov and M.A. Semikhatov}

\section{REFERENCES}

Aksenov, E.M., Keller, B.M., Sokolov, B.S., et al., General stratigraphic scheme of the Upper Precambrian in the Russian Platform, Izv. Akad. Nauk SSSR, Ser. Geol., 1978, no. 12 , pp. $17-34$.

Aksenov, E.M., The Vendian in the East European Platform, in Vendskaya sistema. Istoriko-geologicheskoe i paleontologicheskoe obosnovanie. T. 2. Stratigrafiya i geologicheskie protsessy (The Vendian System: Historical-Geological and Paleontological Substantiation. Vol. 2. Stratigraphy and Geological Processes), Sokolov, B.S. and Fedonkin, M.A. Eds., Moscow: Nauka, 1985, pp. 3-34.

Bekker, Yu.R., Molassy dokembriya (Precambrian Molasses), Leningrad: Nauka, 1988 [in Russian].

Brasier, M.D., Background to the Cambrian explosion, J. Geol. Soc., 1992, vol. 149, pp. 585-587.

Brasier, M.D. and Lindsay, J.F., Did supercontinental amalgamation trigger the "Cambrian Explosion"? in The Ecology of the Cambrian Radiation, Zhuravlev, A. and Riding, R., Eds., New York: Columbia Univ. Press, 2001, pp. 69-89.

Burzin, M.B., Trends in the evolution of benthic vegetation during the Late Precambrian, Algologiya, 1996, vol. 6, no. 4, pp. 407-426.
Butterfield, N.J., Animals and the invention of the Phanerozoic Earth System, Trends in Ecology Evolution, 2011, vol. 26, no. 2, pp. 81-87.

Condie, K.C. and Wronkiewicz, D.A., The Cr/Th ratio in Precambrian pelites from the Kaapvaal Craton as an index of craton evolution, Earth Planet. Sci. Lett., 1990, vol. 97, pp. 256-267.

Condie, K.C., Chemical composition and evolution of the upper continental crust: contrasting results from surface samples and shales, Chem. Geol., 1993, vol. 104, pp. 1-37.

Cox, R., Lowe, D.R., and Cullers, R.L., The influence of sediment recycling and basement composition on evolution of mudrock chemistry in the south-western United States, Geochim. Cosmochim. Acta, 1995, vol. 59, pp. 2919-2940.

Cullers, R.L., The control on the major- and trace-element evolution of shales, siltstones and sandstones of Ordovician to Tertiary age in the Wet Mountains region, Colorado, USA, Chem. Geol., 1995, vol. 123, pp. 107-131.

Darroch, S.A.F., Sperling, E.A., Boag, T.H., et al., Biotic replacement and mass extinction of the Ediacara biota, Proc. R. Soc. B., 2015. doi 10.1098/rspb.2015.1003

Dronov, A., Tolmacheva, T., Raevskaya, E., and Nestell, M., Cambrian and Ordovician of St. Peterburg Region, St. Petersburg: St. Petersburg State Univ., All-Russ. Res. Geol. Inst., 2005.

Erofeev, V.S. and Tsekhovskii, Yu.G., Parageneticheskie assotsiatsii kontinental'nykh otlozhenii (Semeistvo aridnykh paragenezov. Evolyutsionnaya periodichnost') (Paragenetic Associations of Continental Deposits (Family of Arid Parageneses. Evolutionary Periodicity), Moscow: Nauka, 1983 [in Russian].

Fedo, C.M., Nesbitt, H.W., and Young, G.M., Unraveling the effects of potassium metasomatism in sedimentary rocks and paleosols, with implications for paleoweathering conditions and provenance, Geology, 1995, vol. 23, pp. 921-924.

Gagen-Torn, O.Ya., Structural features of clays of the Voronkovskaya Formation (Upper Vendian), in Mater. I Mezhd. rabochego soveshch. "Gliny, glinistye mineraly $i$ sloistye materialy” (Proc. I Int. Conf. "Clays, Clay Minerals, and Layered Materials"), Moscow: IGEM RAN, 2011.

Gagen-Torn, O.Ya., The structure of Vendian-Cambrian boundary deposits in the clint area in the southern coast of the Gulf of Finland, in Mater. II Vseross. soveshch. "Paleozoi Rossii" (Proc. II All-Russ. Conf. "The Paleozoic of Russia”), St. Petersburg: Vseross. Nauchno-Issled. Inst., 2012, pp. 58-60.

Gavrilov, Yu.O., Shchepetova, E.V., Baraboshkin, E.Yu., and Shcherbinina, E.A., The Early Cretaceous anoxic basin of the Russian Plate: sedimentology and geochemistry, Lithol. Miner. Resour., 2002, vol. 37, no. 4, pp. 310-329.

Geisler, A.N., Paleogeography of the northwestern Russian Platform in Valdaian (Vendian) and Early Cambrian times, in Materialy po paleogeografii i litologii (Materials on Paleogeography and Lithology), Leningrad: Nedra, 1967, pp. 7-35.

Geologicheskii atlas Sankt-Peterburga (Geological Atlas of St. Petersburg), St. Petersburg: Kamil'fo, 2009 [in Russian]. Gnilovskaya, M.B., Mens, K.A., Pashkyavichene, L.T., and Pirrus, E.A., Horizon subdivision of the Upper Vendian in a stratotype area, in Stratigrafiya verkhnego proterozoya SSSR (Rifei $i$ Vend) (Upper Proterozoic Stratigraphy of the USSR (Riphean and Vendian)), Keller, B.M. and 
Semikhatov, M.A., Eds., Leningrad: Nauka, 1979, pp. 117121.

Golubkova, E.Yu., Zaitseva, T.S., Kuznetsov, A.B., et al., Microfossils and $\mathrm{Rb}-\mathrm{Sr}$ age of glauconite in the key section of the Upper Proterozoic of the northeastern part of the Russian plate (Keltmen-1 borehole), Dokl. Earth Sci., 2015, vol. 462, no. 2, pp. 547-551.

Golubkova, E.Yu., Kushim, K.A., and Plotkina, Yu.V., Paleontological characteristics of Vendian-Cambrian boundary deposits of the northwestern Russian Plate, in Mater. LXII Ses. Paleontol. obshch. (Proc. LXII Sess. Paleontol. Soc.), St. Petersburg: Vseross. Nauchno-Issled. Inst., 2016, pp. 55-57.

Gorokhov, I.M., Clauer, N., Turchenco, T.L., et al., Rb-Sr systematics of Vendian-Cambrian claystones from the East European Platform: implications for a multi-stage illite evolution, Chem. Geol., 1994, vol. 112, pp. 71-89.

Gorokhov, I.M., Melnikov, N.N., Kuznetsov, A.B., et al., $\mathrm{Sm}-\mathrm{Nd}$ systematics of fine-grained fractions of the Lower Cambrian blue clay in northern Estonia, Lithol. Miner. Resour., 2007, vol. 42, no. 5, pp. 482-495.

Grazhdankin, D.V. and Maslov, A.V., Sequence stratigraphy of the Upper Vendian of the East European Craton, Dokl. Earth Sci., 2009, vol. 426, no. 1, pp. 517-521.

Grazhdankin, D.V., Marusin, V.V., Meert, J., et al., Kotlin Regional Stage in the South Urals, Dokl. Earth Sci., 2011, vol. 440, no. 1, pp. 1222-1226.

Grazhdankin, D., Patterns of evolution of the Ediacaran soft-bodied biota, J. Paleontol., 2014, vol. 88, no. 2, pp. 269283.

Grazhdankin, D.V. and Maslov, A.V., The room for the Vendian in the International Chronostratigraphic Chart, Russ. Geol. Geophys., 2015, vol. 56, no. 4, pp. 549-559.

Hatch, J.R. and Leventhal, J.S., Relationship between inferred redox potential of the depositional environment and geochemistry of the Upper Pennsylvanian (Missourian) Stark Shale Member of the Dennis Limestone, Wabaunsee County, Kansas, USA, Chem. Geol., 1992, vol. 99, pp. 65-82.

Herron, M.M., Geochemical classification of terrigenous sands and shales from core or log data, J. Sed. Petrol., 1988, vol. 58, pp. 820-829.

Interpretatsiya geokhimicheskikh dannykh (Interpretation of Geochemical Data), Sklyarov, E.V., Ed., Moscow: Internet Inzh., 2001 [in Russian].

Ivleva, A.S., Podkovyrov, V.N., Ershova, V.B., et al., Results of U-Pb LA-ICP-MS dating of detrital zircons from Ediacaran-Early Cambrian deposits of the eastern part of the Baltic Monoclise, Dokl. Earth Sci., 2016, vol. 468 , no. 2 , pp. 593-597.

Jensen, S. and Mens, K., Trace fossils Didymaulichnus cf. Tiransis and Monomorphichnus isp. from the Estonian Lower Cambrian, with the discussion on the early Cambrian ichnocoenoses of Baltica, Proc. Est. Acad. Sci., Geol., 2001, vol. 50, no. 2, pp. 75-85.

Jones, B. and Manning, D.A.C., Comparison of geochemical indices used for the interpretation of palaeoredox conditions in ancient mudstones, Chem. Geol., 1994, vol. 111, pp. 111-129.

Kholodov, V.N. and Nedumov, R.I., Geochemical criteria of $\mathrm{H}_{2} \mathrm{~S}$ contamination in waters of ancient basins, Izv. Akad. Nauk SSSR, Ser. Geol., 1991, no. 12, pp. 74-82.
Kuznetsov, A.B., Semikhatov, M.A., Gorokhov, I.M., et al., $\mathrm{Sr}$ isotope composition in carbonates of the Karatau Group, Southern Urals, and standard curve of ${ }^{87} \mathrm{Sr} /{ }^{86} \mathrm{Sr}$ variations in the Late Riphean Ocean, Stratigr. Geol. Correl., 2003, vol. 11, no. 5, pp. 415-449.

Kuznetsov, N.B., Natapov, L.M., Belousova, E.A., et al., Geochronological, geochemical and isotopic study of detrital zircon suites from late Neoproterozoic clastic strata along the NE margin of the East European Craton: implications for plate tectonic models, Gondwana Res., 2010, vol. 17, pp. 583-601.

Laflamme, M., Darroch, S.A.F., Tweedt, S., et al., The end of the Ediacara biota: extinction, biotic replacement, or Cheshire Cat? Gondwana Res., 2013, vol. 23, pp. 558-573.

Lenton, T., Boyle, R.A., Poulton, S.W., et al., Co-evolution of eukaryotes and ocean oxygenation in the Neoproterozoic era, Nature Geosci., 2014, vol. 7, no. 4, pp. 257-265.

Marusin, V.V., Grazhdankin, D.V., and Maslov, A.V., Redkino stage in evolution of Vendian macrophytes, Dokl. Earth Sci., 2011, vol. 436, no. 5, pp. 197-202.

Maslov, A.V., Krupenin, M.T., Gareev, E.Z., and Petrov, G.A., Assessment of redox environments in Riphean and Vendian sedimentary basins on the western slope of the Urals, Litosfera, 2003, no. 2, pp. 75-93.

Maslov, A.V., Osadochnye porody: metody izucheniya i interpretatsii poluchennykh dannykh (Sedimentary Rocks: Methods of Study and Interpretation of Obtained Data), Yekaterinburg: Ural. Gos. Gorn. Univ., 2005 [in Russian].

Maslov, A.V. and Podkovyrov, V.N., The correlation of mesoscale geochemical cycles in sequences of the north, north-east, and east of the East European Platform and the western megazone of the Urals, in Problemy mineralogii, petrografii i metallogenii. Materialy nauchnykh chtenii pamyati P.N. Chirvinskogo. Vyp. 13 (Proc. P.N. Chirvinskii Sci. Readings "Problems in Mineralogy, Petrography, and Metallogeny"), Perm: Perm. Gos. Univ., 2010, pp. 272-279.

Maslov, A.V., Podkovyrov, V.N., and Gareev, E.Z., Evolution of the paleogeodynamic settings of the formation of the Lower and Middle Riphean sedimentary sequences of the Uchur-Maya region and the Bashkir meganticlinorium, Russ. J. Pacific Geol., 2012, vol. 6, no. 5, pp. 382-394.

Maslov, A.V., Litogeokhimiya terrigennykh porod verkhnego dokembriya Volgo-Ural'skoi oblasti (Lithogeochemistry of the Upper Precambrian Terrigenous Rocks in the Volga-Ural Region), Yekaterinburg: Red.-Izdat. Otdel Ural. Otd. Russ. Akad. Nauk., 2012 [in Russian].

Maslov, A.V., Grazhdankin, D.V., Podkovyrov, V.N., and Krupenin, M.T., Unique features of changes of several lithogeochemical characteristics of the Upper Vendian fine-grained clastic rocks in the Mezen paleobasin, Litosfera, 2013, no. 3, pp. 25-42.

Maynard, J.B., Valloni, R., and Yu, H.-Sh., Composition of modern deep-sea sands from arc-related basins, Spec. Publ.-Geol. Soc. London, 1982, vol. 10, pp. 551-561.

McLennan, S.M., Rare earth elements in sedimentary rocks: influence of provenance and sedimentary processes, in Geochemistry and Mineralogy of Rare Earth Elements, Lipin B.R., McKay G.A., Eds., Rev. Mineral, 1989, vol. 21, pp. 169-200.

McLennan, S.M., Hemming, S., McDaniel, D.K., and Hanson, G.N., Geochemical approaches to sedimentation, provenance, and tectonics, in Processes Controlling the Com- 
position of Clastic Sediments, Johnsson M.J. and Basu A., Eds., Spec. Pap. - Geol. Soc. Am., 1993, no. 284, pp. 21-40.

Mens, K.A. and Pirrus, E.A., On the stratigraphy of Vendian-Cambrian boundary beds in the northwestern Russian Platform, Izv. Akad. Nauk SSSR, Ser. Geol., 1971, no. 11, pp. 93-103.

Mens, K. and Pirrus, E., North Baltic facial profile of the Vendian and Cambrian deposits, in Fatsii $i$ stratigrafiya venda $i$ kembriya zapada Vostochno-Evropeiskoi platformy (Vendian-Cambrian Facies and Stratigraphy of the Western Part of East European Platform), Pirrus, E.A., Ed., Tallinn: Inst. Geol. Akad. Nauk Estonskoi SSR, 1986, pp. 7-23.

Mens, K. and Pirrus, E., Stratigraphic gaps in the VendianCambrian Sequence of the North Baltics, Izv. Akad. Nauk Estonskoi SSR. Ser. Geol., 1987, vol. 36, no. 2, pp. 49-57.

Nesbitt, H.W. and Young, G.M., Early Proterozoic climates and plate motions inferred from major element chemistry of lutites, Nature, 1982, vol. 19, pp. 715-717.

Palegeografiya $i$ litologiya venda $i$ kembriya zapada Vostochno-Evropeiskoi platformy (Vendian and Cambrian Paleogeography and Lithology of the Western Part of East European Platform), Moscow: Nauka, 1980 [in Russian].

Podkovyrov, V.N., Lithological and geochemical trends in Upper Vendian sedimentary sequences of the western Moscow Syneclise, in Mater. 8-go Ural. litol. soveshch. "Aktual'nye voprosy litologii" (Proc. 8th Ural. Lithol. Conf. "Actual Problems in Lithology"), Yekaterinburg: Inst Geol. Geokhim. UrO RAN, 2010, pp. 246-247.

Põldvere, A., Isozaki, Y., Bauert, H., et al., Provenance of the Lower-Middle Paleozoic of Estonia in central Baltica: a possible link to Avalonia, GFF, 2014, vol. 136, pp. 214-217.

Postanovleniya Mezhvedomstvennogo stratigraficheskogo komiteta i ego postoyannykh komissii. Vyp. 40 (Resolutions of the Interdepartmental Stratigraphic Committee and Its Permanent Commissions, no. 40), Zhamoida, A.I., Ed., St. Petersburg: Vseross. Nauchno-Issled. Inst., 2011 [in Russian].

Rannii dokembrii Baltiiskogo shchita (Early Precambrian of the Baltic Shield), Glebovitskii, V.A., Ed., St. Petersburg: Nauka, 2005 [in Russian].

Resheniya Mezhvedomstvennogo soveshchaniya po razrabotke unifitsirovannykh stratigraficheskikh skhem verkhnego dokembriya i paleozoya Russkoi platformy, 1962 (Decisions of the Interdepartmental Conference on the Development of Unified Stratigraphic Schemes for the Upper Precambrian and Paleozoic of the Russian Platform, 1962), Leningrad: Nedra, 1965 [in Russian].

Rimmer, S.M., Geochemical paleoredox indicators in Devonian-Mississippian black shales, Central Appalachian Basin (USA), Chem. Geol., 2004, vol. 206, pp. 373-391.

Rollinson, H.R., Using Geochemical Data: Evaluation, Presentation, Interpretation, Essex: London Group UK Ltd, 1994.
Ronkin, Yu.L., Grazhdankin, D.V., Maslov, A.V., et al., $\mathrm{U}-\mathrm{Pb}$ (SHRIMP II) age of zircons from ash beds of the Chernokamen Formation, Vendian Sylvitsa group (Central Urals), Dokl. Earth Sci., 2006, vol. 411, no. 2, pp. 13411345.

Roser, B.D. and Korsch, R.J., Determination of tectonic setting of sandstone-mudstone suites using $\mathrm{SiO}_{2}$ content and $\mathrm{K}_{2} \mathrm{O} / \mathrm{Na}_{2} \mathrm{O}$ ratio, J. Geol., 1986, vol. 94, pp. 635-650.

Rudnick, R.L. and Gao, S., Composition of the continental crust, in Treatise Geochem., vol. 3, Elsevier, 2003, pp. 1-64. Stratigrafiya verkhnedokembriiskikh i kembriiskikh otlozhenii zapada Vostochno-Evropeiskoi platformy (Stratigraphy of Upper Precambrian and Cambrian Deposits of the Western Part of East European Platform), Moscow: Nauka, 1979 [in Russian].

Suttner, L.J. and Dutta, P.K., Alluvial sandstones composition and paleoclimate, I, framework mineralogy, J. Sed. Petrol., 1986, vol. 56, pp. 329-345.

Taylor, S.R. and McLennan, S.M., Continental Crust: its Composition and Evolution, London: Blackwell, 1985.

Verbitskii, V.R., Verbitskii, I.V., Vasil'eva, O.V., et al., Gosudarstvennaya geologicheskaya karta Rossiiskoi Federatsii. Masshtab 1 : 1000000 (tret'e pokolenie). Seriya Tsentral'noEvropeiskaya. Listy O-35 (Pskov), (N-35), O-36 (SanktPeterburg). Obyasnitel"naya zapiska (The 1: 1000000 State Geological Map of the Russian Federation, the 3rd ed. Central Europe Ser. Sheets O-35 (Pskov), (N-35), O-36 (St. Petersburg). Explanatory Note)), St. Petersburg: Kartfabrika Vseross. Nauchno-Issled. Inst., 2012 [in Russian].

Vorob'eva, N.G., Sergeev, V.N., and Knoll, A.N., Neoproterozoic microfossils from the northeastern margin of the East European Platform, J. Palaeontol., 2009, vol. 83, no. 2, pp. 161-196.

Vorob'eva, N.G. and Petrov, P.Yu., The genus Vendomyces Burzin and facies-ecological specificity of the Staraya Rechka microbiota of the Late Vendian of the Anabar Uplift of Siberia and its stratigraphic analogues, J. Paleontol., 2014, vol. 48, no. 6, pp. 655-666.

Yudovich, Ya.E. and Ketris, M.P., Osnovy Litokhimii (Principles of Lithochemistry), St. Petersburg: Nauka, 2000 [in Russian].

Zaitseva, T.S., Gorokhov, I.M., Ivanovskaya, T.A., et al., Mössbauer characteristics, mineralogy and isotopic age (Rb-Sr, K-Ar) of Upper Riphean glauconites from the UK Formation, the southern Urals, Stratigr. Geol. Correl., 2008, vol. 16 , no. 3 , pp. 227-247.

Zhamoida, A.I., Obshchaya stratigraficheskaya shkala, prinyataya v SSSR-Rossii. Ee znachenie, naznachenie i sovershenstvovanie (The General Stratigraphic Scale Adopted in the USSR and Russia: Its Significance, Purpose, and Improvement), St. Petersburg: Vseross. Nauchno-Issled. Inst., 2013 [in Russian].

Translated by I. Basov 